\title{
Neuropeptides in asthma, chronic obstructive pulmonary disease and cystic fibrosis
}

\author{
Kalina R. Atanasova and Leah R. Reznikov * (D)
}

\begin{abstract}
The nervous system mediates key airway protective behaviors, including cough, mucus secretion, and airway smooth muscle contraction. Thus, its involvement and potential involvement in several airway diseases has become increasingly recognized. In the current review, we focus on the contribution of select neuropeptides in three distinct airway diseases: asthma, chronic obstructive pulmonary disease (COPD), and cystic fibrosis. We present data on some well-studied neuropeptides, as well as call attention to a few that have not received much consideration. Because mucus hypersecretion and mucus obstruction are common features of many airway diseases, we place special emphasis on the contribution of neuropeptides to mucus secretion. Finally, we highlight evidence implicating involvement of neuropeptides in mucus phenotypes in asthma, COPD and cystic fibrosis, as well as bring to light knowledge that is still lacking in the field.
\end{abstract}

Keywords: Neuropeptides, Lung diseases, Mucus, Cystic fibrosis, Asthma, COPD

\section{Background}

Lung diseases are among the top 5 mortality-causing diseases in the World [1]. As with many organs, lung diseases vary significantly in their etiology and pathology, ranging from inherited genetic diseases like cystic fibrosis (CF), to allergic and inflammatory disorder diseases, such as asthma and chronic obstructive pulmonary disease (COPD). Although hallmark features of asthma, COPD, and CF differ, mucus obstruction is a common attribute among all [2]. Studies examining asthma, COPD and CF have focused on the role of the immune system [3-7] and epithelial ion channels in mucus secretion [8-12], but the involvement of the nervous system, and in particular neuropeptide signaling, remains a field of much unknowns [13]. This is important given the rich innervation of the airway and its modulatory role in mucus secretion [14-19]. The goal of this review is to summarize the current knowledge on the effects of select neuropeptides in the lungs, with an emphasis on asthma, COPD and CF. A specific interest is

\footnotetext{
* Correspondence: leahreznikov@ufl.edu

Department of Physiological Sciences, College of Veterinary Medicine,

University of Florida, 1333 Center Drive, PO Box 100144, Gainesville, FL 32610, USA
}

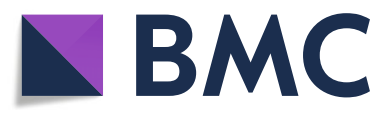

(c) The Author(s). 2018 Open Access This article is distributed under the terms of the Creative Commons Attribution 4.0 International License (http://creativecommons.org/licenses/by/4.0/), which permits unrestricted use, distribution, and

reproduction in any medium, provided you give appropriate credit to the original author(s) and the source, provide a link to the Creative Commons license, and indicate if changes were made. The Creative Commons Public Domain Dedication waiver (http://creativecommons.org/publicdomain/zero/1.0/) applies to the data made available in this article, unless otherwise stated. placed on neuropeptide-mediated regulation of mucus secretion and their effects on the expression of the two major secreted gel-forming mucins in the airway, mucin5AC (muc5AC) and mucin5B (muc5B) [20].

Neuropeptides, by definition, are peptides that are formed by the enzymatic processing of gene-encoded precursor molecules [21]. They are produced, stored, and secreted upon demand via regulated secretory pathways. Due to different enzyme cleaving and processing the precursor molecules, current neuropeptides are classified into families based upon the genes encoding those precursors $[21,22]$. The molecules that fit this definition are called "classic neuropeptides". However, with increased interest and evolving research, new members are constantly emerging, and the definition continues to expand as new molecules that have some neuropeptide features, but lack others, are discovered [21]. Expression of precursor molecules occurs predominantly in neurons where they are stored in large granular vesicles in the cytoplasm and released upon stimulation [21, 23]. After their release, classical neuropeptides exert their specific actions upon a variety of target cells via G-protein

\section{Neuropeptides production and secretion}


coupled receptors [21, 23]. Their actions can be exerted on other neurons as modulators of signaling, or on non-neuronal cells as signaling molecules. Therefore in many organs, neuropeptides can exert effects through direct innervation of the end organ (synaptic contact), but also through non-synaptic contact and paracrine activity on neighboring cells [21]. Additionally, more than one receptor type and different G-protein coupling of neuropeptide receptors in different tissues lead to variable effects of the same neuropeptides in different tissues/cell types [24-36]. This also adds to the complexity observed in the effects of neuropeptides.

Many neuropeptides co-exist in the same neurons, where they influence production and secretion of one another, thus exerting a neuromodulatory role [21, 23, 37]. Because of this, predicting the consequences of neuropeptide release and/or activation can be difficult. Moreover, in the lung, non-neuronal cells, known as neuroendocrine cells, synthesize and secrete neuropeptides. These cells add an additional layer of regulation and have recently gained interest in asthma and CF [38-44].

\section{Neuropeptides in asthma, COPD and cystic fibrosis}

Asthma and COPD are common, chronic, and heterogeneous pulmonary diseases that have a significant impact on quality of life [45]. Asthma is primarily viewed as an inflammatory disorder of the airways and often is diagnosed at young age [37]. It is characterized by wheezing, cough, chest tightness and variable airflow limitation that is partially reversible $[37,46]$. Key features of asthma include airway hyperreactivity, as well as alterations in the quantity and quality of airway mucus [18, 47, 48]. Although inflammation is a cornerstone of asthma [49], several studies have shown that the nervous system plays a fundamental role in its pathogenesis [50-53].

Unlike asthma, COPD almost exclusively affects adult populations and is often related to long-term exposure to tobacco smoke or other chemicals [54-56]. Inflammation, persistent airflow limitation, and mucus obstruction are also salient features [57]. The role of the nervous system in COPD is still being elucidated [58-61].

In contrast to both asthma and COPD [62], CF is a single gene disorder that arises from mutations in the cystic fibrosis conductance regulator (CFTR) gene [63]. Mutations in CFTR result in faulty ion transport, which in the airway impairs several key airway host defenses (reviewed here [64, 65]. Features of CF include mucus obstruction and recurrent airway infections. Neural involvement in CF has been proposed [66-68].

Here we review a few select neuropeptides that have either been shown to impact or have the potential to impact the pathogenesis and progression of either asthma, COPD, or CF. Special emphasis is placed on neuropeptides that have not received much attention, and/or those that have been recently discovered. We summarize the involvement of these neuropeptides in mucus secretion in Table 1, and their effects on mucus secretion in asthma, COPD, and CF in Fig. 1. Further, a summary of the expression and/or release of these neuropeptides in people with asthma, COPD, or CF is provided in Table 2. Fig. 2 and Table 3 provide a summary of the known/proposed G-protein coupled receptors mediating the effects of the select neuropeptides.

\section{Tachykinins}

Tachykinins are a group of neuropeptides that are enzymatically cleaved from precursor proteins to form 10-12aa biologically active products [69]. The two major gene products that encode tachykinins are the preprotachykinin A (TAC1) gene - the parent of Substance P (SubP) and neurokinin A (NKA), and preprotachykinin B (TAC3) gene - encoding the precursor of neurokinin $B(\mathrm{NKB})$ $[21,69,70]$. Of these, Sub P is the best studied. SubP and NKA, but not NKB, are localized to sensory nerves that are situated beneath and within the airway epithelium

Table 1 General overview of neuropeptides and their effect on airway mucus secretion

\begin{tabular}{|c|c|}
\hline Neuropeptide & General effect on mucus secretion \\
\hline \multirow[t]{3}{*}{$\begin{array}{l}\text { Calcitonin gene-related } \\
\text { peptide (CGRP) }\end{array}$} & $\begin{array}{l}\text { Induced small concentration-dependent } \\
\text { increases in basal mucus volume, lysozyme } \\
\text { and albumin outputs from in vitro ferret } \\
\text { trachea culture at baseline [143]. }\end{array}$ \\
\hline & $\begin{array}{l}\text { Stimulated goblet cell hyperplasia when } \\
\text { co-administered with GABA [39]. }\end{array}$ \\
\hline & Stimulate goblet cell secretion [142] \\
\hline \multirow[t]{2}{*}{ Bombesins } & $\begin{array}{l}\text { GRP-27 induced dose-dependent increase of } \\
\text { respiratory glycoconjugate secretion in feline } \\
\text { tracheal organ culture [201]. }\end{array}$ \\
\hline & $\begin{array}{l}\text { Bombesin receptor-activated protein BRAP } \\
\text { (a downstream protein from the activation of } \\
\text { the orphan bombesin receptor subtype-3) } \\
\text { regulates neutrophil elastase-induced muc5AC } \\
\text { hypersecretion in human bronchial epithelial } \\
\text { cell line [207]. }\end{array}$ \\
\hline \multirow[t]{2}{*}{ Substance P (SubP) } & $\begin{array}{l}\text { Stimulates human airway submucosal gland } \\
\text { secretion }[76,79] \text {. }\end{array}$ \\
\hline & Increases goblet cell secretion [142]. \\
\hline Granins & $\begin{array}{l}\text { Secretoneurin induced Muc5AC hypersecretion } \\
\text { in a dose- and time-dependent manner in } \\
\text { human HBE16 bronchial epithelial cell line [36]. }\end{array}$ \\
\hline \multirow[t]{2}{*}{$\begin{array}{l}\text { Vasoactive intestinal } \\
\text { peptide (VIP) }\end{array}$} & $\begin{array}{l}\text { Stimulates mucus secretion in ferret trachea } \\
\text { [113]. }\end{array}$ \\
\hline & $\begin{array}{l}\text { Knockout of the VIP receptor (VPAC2) in a } \\
\text { murine model of Aspergillus antigen-induced } \\
\text { asthma lead to a marked enhancement of } \\
\text { MUC5AC mRNA and an associated increase in } \\
\text { goblet cells in the lungs [232]. }\end{array}$ \\
\hline Neuropeptide Y & $\begin{array}{l}\text { Modulates mucus output from airway } \\
\text { submucosal glands }[173,174] \text {. }\end{array}$ \\
\hline
\end{tabular}




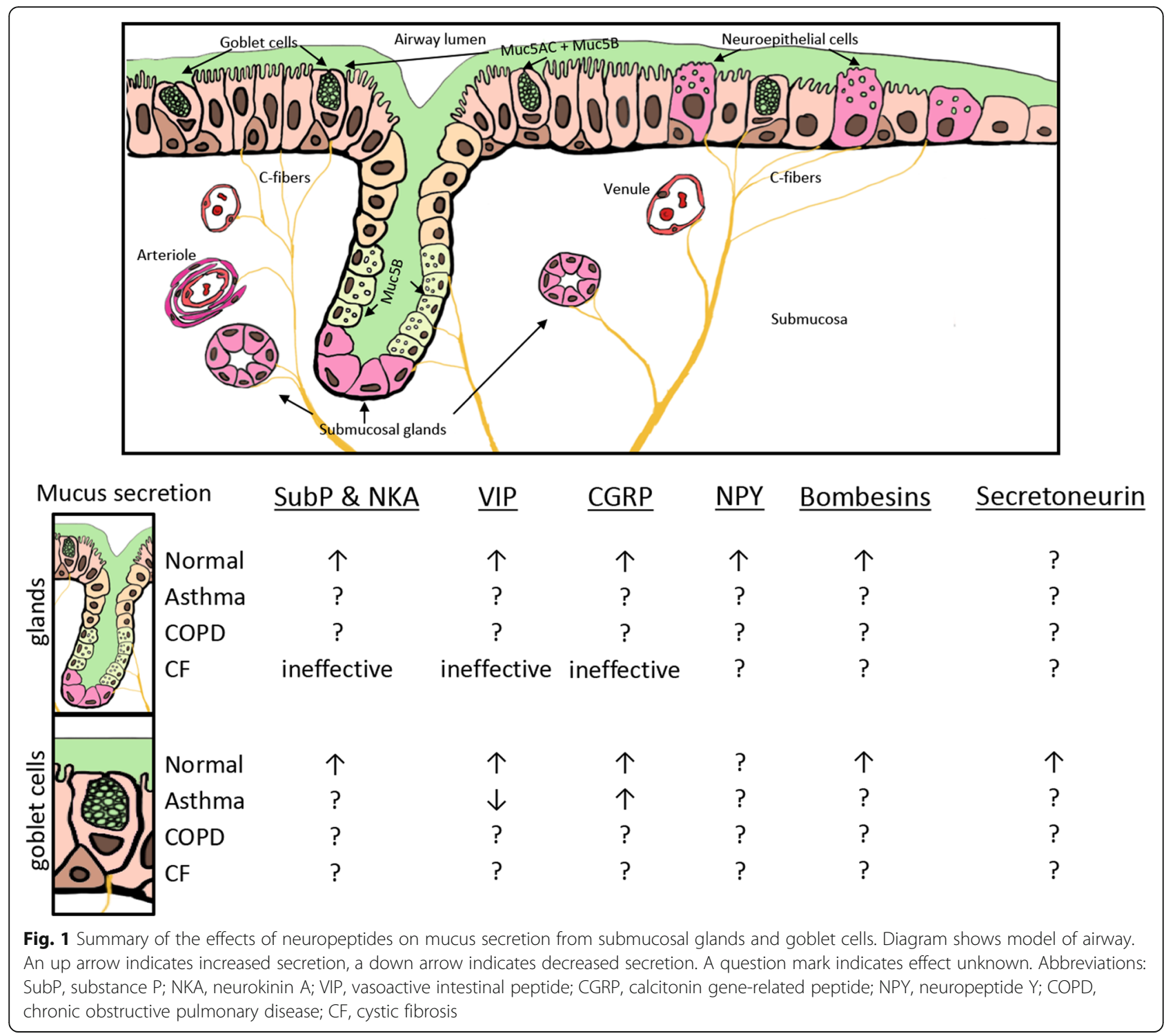

(C-fibers), around blood vessels, and to a lesser degree within airway smooth muscle $[37,71]$. Their effects are mediated via NK1 receptors (mainly for SubP) and NK2 receptors (activated by NKA). Activation of these receptors induces airway smooth muscle constriction in humans, although the effects of SubP are variable [72-75]. SubP also has a direct effect on airway goblet cells and submucosal glands through NK1 receptor, causing mucus secretion [76-79]. Using receptor antagonists against NK1 and NK3 receptors in porcine tracheal explants, Philips and colleagues showed that SubP and NKB induced submucosal gland fluid flux, while NKA had no effect on the gland flux [80]. Their results also suggested that NK1 and NK3 receptors may induce glandular effects by different mechanisms - NK3 receptors are likely inducing activation of parasympathetic nerves, while NK1 may have direct effect on the glands [80].

\section{Asthma}

In asthmatic airways, mucus content positively correlated with SubP expression; NK1 receptors were also elevated with strongest expression detected on goblet cells [81]. The authors of that study concluded that neurogenic mechanisms contributed to asthma. Consistent with that, Tomaki and colleagues found that SubP levels in sputum correlated with airway obstruction in asthma [82]. In an experimental murine model of allergic asthma, increased bronchoalveolar lavage fluid concentrations of SubP were associated with induction of muc5AC mRNA [83], further suggesting a potential pathogenic role for tachykinins in asthma. Other studies have found a positive correlation between muc5AC and NKA protein expression in the sputum of asthmatics [84]. There are currently no studies available that provide information regarding the role of $\mathrm{NKB}$ in regulating muc5AC or muc5B expression, nor of SubP or NKA in the regulation of 


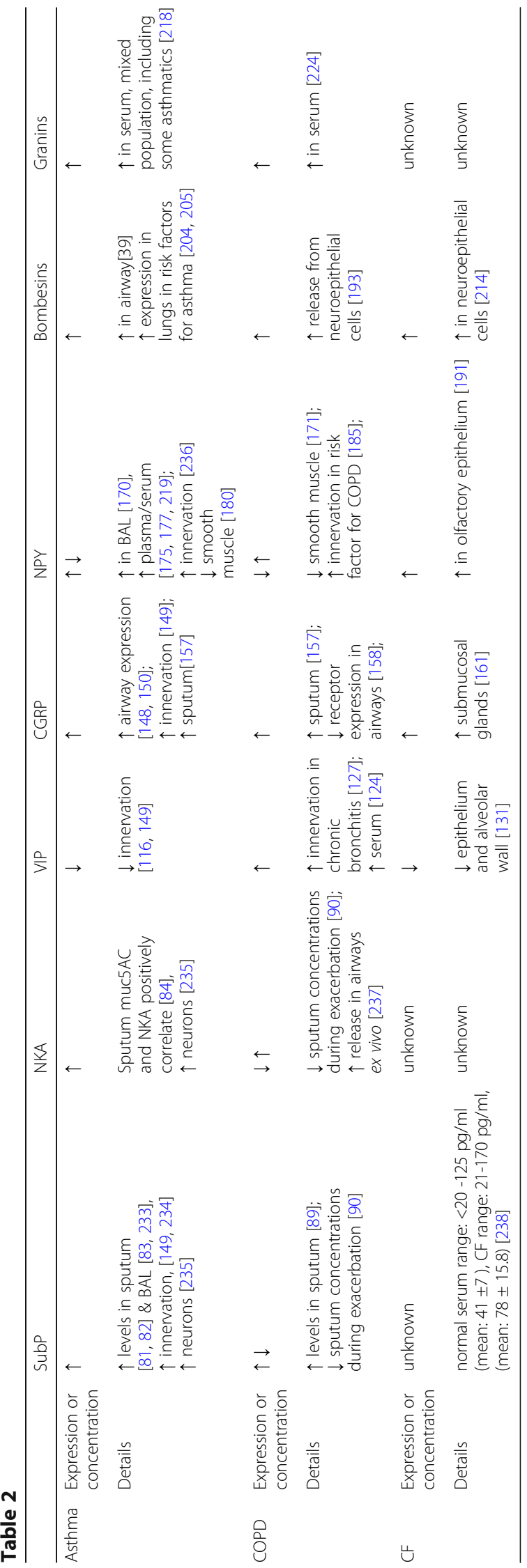




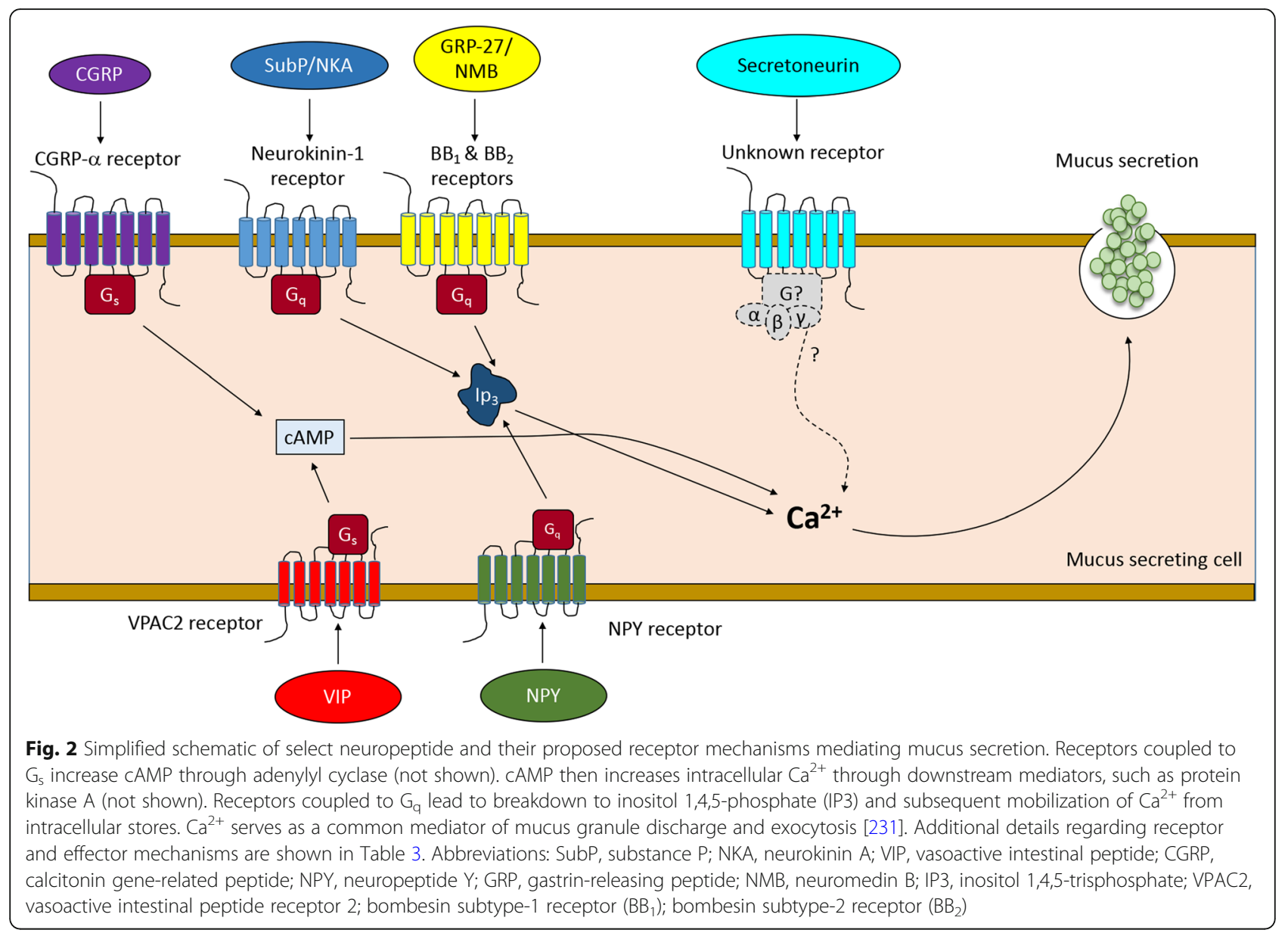

muc5B, in asthma. However, given that muc5AC is increased and muc5B decreased in the sputum obtained from asthmatics [48], it is possible (although speculative) that tachykinins have stimulatory roles on muc5AC, but inhibitory roles on muc5B.
Therapeutically, tachykinin receptor antagonists have been explored in asthma, with some reports suggesting beneficial effects (reviewed here [85]). For such studies, bronchoconstriction, inflammation and lung function were primary endpoints. For example, Van Schoor and

Table 3 Receptor mechanisms of select neuropeptides

\begin{tabular}{|c|c|c|}
\hline Neuropeptide & Receptor & Effectors \& signaling molecules involved \\
\hline Substance P/ Neurokinin A & $\begin{array}{l}\text { neurokinin-1,2 \& } 3 \text { receptors (NK-1,2 \&3) } \\
\text { (discussed and reviewed in [239] and [240]). }\end{array}$ & $\begin{array}{l}\mathrm{G}_{\mathrm{s}} \text { and } \mathrm{G}_{\mathrm{q}}[241-243] . \\
\uparrow \text { intracellular } \mathrm{Ca}^{2+}, \mathrm{DAG}, \mathrm{CAMP}, \mathrm{IP3}[79,239,244-246] . \\
\text { CFTR has been implicated [100]. }\end{array}$ \\
\hline VIP & VPAC1, VPAC2 and PAC1 $[30,247]$ & $\begin{array}{l}\mathrm{G}_{\mathrm{s}}, \mathrm{G}_{\mathrm{i}} \text { and } \mathrm{G}_{\mathrm{q}}[248,249] . \\
\uparrow \text { intracellular } \mathrm{Ca}^{2+}, \mathrm{DAG}, \mathrm{CAMP}, \mathrm{IP3}, \text { [249]. } \\
\text { CFTR has been implicated [132]. }\end{array}$ \\
\hline CGRP & CGRP- $\alpha$ subtype and CGRP- $\beta$ subtype $[31,138,250]$. & $\begin{array}{l}\mathrm{G}_{q} \text { and } \mathrm{G}_{s}[251] . \\
\uparrow \text { intracellular } \mathrm{Ca}^{2+}, \mathrm{DAG}, \mathrm{IP} 3, \mathrm{CAMP}[251,252] .\end{array}$ \\
\hline NPY & $\mathrm{Y}-1, \mathrm{Y}-2, \mathrm{Y}-4$ and $\mathrm{Y}-5$ receptors $[32,34,182]$ & $\begin{array}{l}\mathrm{G}_{\mathrm{i}} \text { and } \mathrm{G}_{\mathrm{q}}[182,253] . \\
\uparrow \text { intracellular } \mathrm{Ca}^{2+}, \mathrm{DAG}, \mathrm{CAMP}, \mathrm{IP3},[182,253-256] .\end{array}$ \\
\hline Bombesins (GRP-27; NMB) & $\begin{array}{l}\mathrm{NMB}=\text { subtype } 1 \text { receptor }\left(\mathrm{BB}_{1}\right) \\
\text { GRP-27 = subtype } 2 \text { receptor }\left(\mathrm{BB}_{2}\right) \\
\text { subtype-3 }\left(\mathrm{BB}_{3}\right)=\text { orphan }[35]\end{array}$ & $\begin{array}{l}\mathrm{G}_{i} \text { and } \mathrm{G}_{\mathrm{q}}[35] . \\
\uparrow \text { intracellular } \mathrm{Ca}^{2+}, \mathrm{DAG}, \mathrm{CAMP}, \mathrm{IP3}[35,257] .\end{array}$ \\
\hline Chromogranins (Secretoneurin) & $\begin{array}{l}\text { Currently suspected, but not } \\
\text { identified G-protein coupled receptor. }\end{array}$ & $\uparrow$ intracellular $\mathrm{Ca}^{2+}$, cAMP [36]. \\
\hline
\end{tabular}


colleagues found that SR 48969, a NK2 receptor antagonist, prevented bronchoconstriction provoked by NKA in mild asthmatics [86]. However, more recently, the NK1/ NK2 receptor antagonist AVE5883 has provided mixed results, in which it mitigated NKA-mediated bronchoconstriction, but augmented allergen-induced decreases in forced expiratory volume $\left(\mathrm{FEV}_{1}\right)$ in people with asthma [87]. Because decreases in $\mathrm{FEV}_{1}$ could be due to either bronchoconstriction and/or mucus obstruction, it is possible that dual blockade of NK1 and NK2 receptors in asthmatics augmented mucus secretion and/or bronchoconstriction to allergen. Therefore, examining expression of muc5AC and muc5B in the sputum of people with asthma provided tachykinin receptor antagonists might be especially important. Finally, despite some evidence that tachykinin receptor antagonists might be beneficial, they have failed to reach the market for asthma [88].

\section{COPD}

One report suggests that the concentration of SubP is elevated in the sputum of COPD patients [89], and it was suggested that neurogenic inflammation might contribute to the airway narrowing in COPD. Interestingly, however, in individuals with COPD, sputum SubP and NKA decreased during exacerbation [90]. The authors proposed that continual stimulation of sensory nerves during an exacerbation might have led to neuropeptide depletion, thus accounting for the decreased content. Additional studies have shown that cigarette smoke induces mucus secretion of goblet cells through activation of sensory nerve fibers [91], with SubP being the proposed mediator. Thus, since smoking is a major risk factor for COPD [92, 93], these findings suggested that tachykinin antagonists might be beneficial for COPD [29]. Furthermore, if SubP does mediate cigarette-induced secretion of goblet cells, then it is possible that it might also contribute to increased expulsion of mucus in COPD airways and/or regulate muc5AC and muc5B expression.

Therapeutically, tachykinin receptor antagonists have been shown to decrease inflammation in animal models of COPD [94]. Specifically, the number of macrophages and dendritic cells was decreased in the lung lavage fluid of mice exposed to cigarette smoke and provided the tachykinin receptor antagonist AVE5883. It is also interesting to note that several studies have found a pro-relaxing effect of SubP and NKA human blood vessels [95]. From this perspective, tachykinin antagonists might be of detriment in subpopulations of people with COPD (e.g., those that have pulmonary hypertension). This might explain why none of the tachykinin receptor antagonists that were in development for COPD [96] have exhibited a clear therapeutic benefit.

\section{Cystic fibrosis}

Although SubP stimulates gland secretion in "normal" submucosal glands, reports suggest that it is ineffective in people with CF [76]. This finding has been reproduced in pigs with CF [97]. An implication from those studies was that defective responses to SubP might contribute to airway pathology in CF. Given that glandular secretion in response to SubP is defective in CF, a speculation is that SubP-mediated secretion in CF might be associated with enhanced muc5AC to muc5B secretion ratios, effectively mimicking asthma [98]. Moreover, in contrast to asthma and COPD, where enhanced SubP and/or tachykinin signaling is potentially pathogenic, a decrease in SubP-mediated secretion in CF might be of detriment [99]. However, restoring SubP-mediated signaling through tachykinin agonists seems like an ineffective strategy in CF because evidence suggests that the defect in SubP-mediated glandular secretion in CF is due to loss of CFTR [100]; thus, CFTR correctors and/or modulators would be required. Even if such a strategy was pursued, the pro-inflammatory effects [101] and potential bronchoconstricting effects [72-75] of tachykinins make this a less appealing option.

\section{Other Kinins}

Recently a new gene and associated peptides have been added to the kinin group, although they do not entirely fulfill the requirements to be classical neuropeptides [69, 102]. These peptides have structural similarity with the known tachykinins but are present in a large variety of tissues and organs and are synthesized mainly by cells of the hematopoietic lineage $[69,102]$. In humans, hemokinin 1 (HK-1), together with endokinins (EK) A, B, C and $\mathrm{D}$, which originate from the different splice variants of the TAC4 gene (preprotachykinin C), have been found [102]. Due to the wide spread of HK-1 in the body, and its preferential affinity to the NK-1 tachykinin receptor, it has been implicated in many diseases (reviewed elsewhere, [103-105]) including asthma and possibly COPD [106-108]. HK-1, EKA and B pro-contractile effects have been shown in ex vivo bronchi both in humans and guinea pigs, although seemingly these effects are mediated through different receptors [109]. Very recently HK-1 has also been shown to cause degranulation of the human mast cell line leukocyte adhesion deficiency-2 (LAD2) [110]. These findings suggest that HK-1 might play an important role in the pathogenesis and symptomology of asthma and COPD.

\section{Vasoactive intestinal peptide (VIP)}

VIP belongs to the glucagon/secretin gene family, with its own VIP gene that transcribes to two prepro-VIP precursors, giving rise to 3 peptides (in humans) - VIP, peptide histidine methionine 27 (PHM-27) and peptide 
histidine methionine 42 (PHV-42) [111]. Major functions of VIP include airway smooth muscle relaxation [112], stimulation of mucus secretion from airway glands and goblet cells [113], and vasodilation [112, 114]. The effects of VIP on mucus secretion in humans are complex as an inhibitory effect of VIP on cholinergic-mediated mucus secretion in human submucosal glands has been reported [115].

\section{Asthma}

Some evidence suggests a functional loss of VIP-innervation to the airways in asthma [116], although this may be secondary to inflammation. It was speculated that the loss of VIP-innervation to the airway diminished the amount of bronchodilation mediated by the nervous system. Athari et al. also found that mucus hypersecretion and muc5AC mRNA were significantly decreased when enzyme-degradation resistant VIP was delivered to the airways of mice with experimentally induced asthma [117]. Although speculative, this finding might suggest that VIP has an inhibitory role on muc5AC expression in asthma. However, perhaps inconsistent with this speculation is data from the pancreas suggesting that VIP increases muc5AC expression [118]. Although we were not able to find any studies concerning the effects of VIP on muc5B regulation and/ or expression in asthma, since muc5B might be decreased in asthma [119], and VIP might also be decreased, then one speculation is that VIP directly stimulates production of muc5B.

In 2003, Linden and colleagues examined the effects of a VIP agonist in asthma and found a short, but effective, bronchodilatory effect [120]. Others have shown that VIP possesses potent anti-inflammatory effects and inhibits eosinophil migration [121]. These properties make it an appealing therapeutic candidate for asthma. However, due to short plasma half-lives, VIP analogs have been met with limited enthusiasm clinically [122]. Efforts to modify formulation and delivery have been ongoing. Very recently, one agonist with sustained release (PB1046) has undergone further development for pulmonary hypertension [123]. Perhaps a renewed interest in VIP analogs will reinvigorate efforts to examine their therapeutic potential in asthma.

\section{COPD}

Increased serum levels of VIP might be a marker of acute exacerbations in COPD [124], although whether they are a cause or consequence is unknown. An argument for consequence is derived from studies suggesting a beneficial effect of inhaled VIP on quality of life in COPD [125], as well as evidence indicating a protective role of VIP against pulmonary hypertension in COPD. However, an argument for causal relationship might be inferred from studies demonstrating that chronic bronchitis, which is a common feature of COPD [126], is associated with increased VIP innervation to the mucus glands [127]. The authors suggested that increased VIP innervation to the mucus glands was linked to increased sputum production.

No studies were available that described VIP-mediated activation of goblet cells or glands in either humans or animal models of COPD. Similarly, we were unable to identify any studies that examined the effects of VIP on muc5AC or muc5B expression in COPD airways. However, receptors for VIP (vasoactive intestinal peptide receptor 1 (VPAC), vasoactive intestinal peptide receptor 2 (VPAC2)) were elevated in the epithelium and glands in biopsies from smokers with chronic bronchitis [128]. This finding might suggest that regulation of mucus secretion by VIP is altered in COPD. Additionally, since CFTR dysfunction is involved in COPD pathogenesis [56], one speculation is that VIP-mediated submucosal gland secretion, which is dependent upon CFTR [129], is impaired in COPD.

Very few studies have examined the therapeutic potential of VIP in COPD. As highlighted above, PB1046 is a VIP agonist with sustained release that is being developed for pulmonary hypertension [123]. Because pulmonary hypertension is common in COPD [130], it is possible that PB1046 will be of clinical value in COPD. However, given that increased VIP innervation to the mucus glands in COPD is proposed to contribute to increased sputum production [126], VIP agonists might be of mixed benefit.

\section{Cystic fibrosis}

Studies suggest that VIP nerve distribution and density are decreased in the airway epithelium, submucosal glands, alveolar walls and blood vessels of people with CF [131]. The decrease in VIP distribution was proposed to be secondary to infection and inflammation. It has also been shown that CF airway glands do not respond to VIP stimulation [129]. This lack of response has been interpreted to indicate that VIP stimulates gland secretion through CFTR-dependent mechanisms [132]. The authors suggested that the lack of VIP-mediated gland secretion might promote a hyper-inflammatory airway environment that contributes to CF lung disease. Interestingly, in mice, lack of VIP evokes CFTR dysfunction, creating a CF-like disease [133]. Together, these finding suggests a potential reciprocal relationship between VIP signaling and CFTR function.

Since VIP is ineffective at stimulating gland secretion in $\mathrm{CF}$, then it seems an unlikely candidate to mediate the increased muc5B concentrations (which is largely expressed in the glands and to a lesser extent in surface goblet cells [134]) that are observed during CF 
exacerbations [135]. It is also unlikely that VIP agonists would be therapeutically beneficial for restoring glandular secretion in CF, since VIP-mediated secretion is dependent upon CFTR [132]. Thus, co-administration with CF correctors or potentiators would be necessary. However, the proposed anti-inflammatory and bronchodilator properties of VIP [121] make it a therapeutic option worth exploring.

\section{Calcitonin gene-related peptide (CGRP)}

CGRP is a member of the calcitonin gene family related neuropeptides and its precursors are encoded by the calcitonin II gene $[136,137]$. CGRP-alpha and -beta precursors are cleaved into two 37aa-long isoforms: $\alpha$-CGRP and $\beta-C G R P$ respectively $[21,114,138]$. CGRP is predominantly expressed in the central and peripheral nervous systems [139, 140]. CGRP-positive nerve fibers that innervate the airways originate from the trigeminal, nodose-jugular and dorsal root ganglia [138]. CGRP is also expressed in pulmonary neuroendocrine cells throughout the airway tree and in the alveoli [37, 141]. CGRP can induce mucus secretion in the airways, from both glands and goblet cells [142, 143]. CGRP also amplifies the pro-contractile effects of capsaicin [144] and electrical field stimulation [145].

\section{Asthma}

CGRP has long been suspected for having important modulatory role in asthma, due to its airway constricting capacity [146, 147]. Indeed, reports suggest that CGRP is increased in the bronchoalveolar lavage fluid of asthmatics and might contribute to the late phase asthmatic reactions following provocation by allergen inhalation [148]. CGRP-positive nerve fibers are also increased in animal models given viral infections, which are risk factors for asthma [149]. Interestingly, Larson and colleagues demonstrated that CGRP is expressed ectopically in mucus cells of ovalbumin (OVA)-sensitized Brown-Norway rats [150]. They suggested that this accumulation of CGRP might represent an additional releasing mechanism involved in quick hypersensitivity responses and mucus secretion. A recent investigation by Sui and colleagues found that a combination of CGRP and gamma-aminobutyric acid (GABA) are responsible for goblet cell hyperplasia and muc5AC induction in a murine model of asthma [39]. Using the same model, they also found that elimination of pulmonary neuroendocrine cells, which express CGRP, decreased the expression of goblet cells and muc5B.

There are currently several small molecules, as well as a monoclonal antibodies [151], that inhibit CGRP signaling [152]. Studies exploring the therapeutic potential of inhibiting CGRP signaling have focused largely on the cardiovascular system [153-156], with an emphasis on migraines. Many of those studies demonstrated an acute beneficial effect, however, liver toxicity associate with frequent use of CGRP small molecule inhibitors has hampered progress. To the best of our knowledge, there are no clinical studies that have examined the potential of CGRP receptor antagonists in clinical populations of asthmatics. However, with several tools available, examining inhibition of CGRP in the context of asthma should be achievable, even if only on a small scale. Based upon studies in animals, it is expected that inhibition of CGRP would alleviate some of the mucus phenotypes in allergic asthma [39].

\section{COPD}

Increased concentrations of CGRP have been identified in the sputum of people with COPD [157], where they have been speculated to play a role in promoting airway inflammation. Similarly, $\mathrm{Gu}$ et al. found increased frequency of CGRP-positive cells in the airways of people with COPD but decreased epithelial expression of CGRP receptors [158]. Although there are no studies that have specifically examined the effects of CGRP on muc5AC or muc5B expression in COPD, finding altered CGRP receptor expression in COPD airway epithelial cells suggests a possible influence of CGRP on muc5AC and muc5B expression. Correlative data also demonstrates a relationship between COPD, notch signaling, muc5AC mRNA, and pulmonary neuroendocrine cells (which synthesize CGRP among many other neuropeptides) [159].

We carefully examined the literature but were unable to find any studies that assessed the therapeutic potential of CGRP antagonists/blockers in preclinical or clinical COPD studies. However, given that CGRP can stimulate smooth muscle contraction in human airways [160], and has been implicated in mucus secretion in normal airways [142, 143], it is predicted that inhibition of CGRP might be of benefit in COPD. Yet, studies indicating that CGRP agonists possess specific anti-inflammatory properties, as well as vasodilatory properties [138], might suggest that inhibiting CGRP could be of potential negative consequence in COPD. Thus, clinical and/or preclinical studies that address the potential benefits of blocking CGRP (or the potential negative consequences) in COPD are necessary.

\section{Cystic fibrosis}

Although CGRP has also been shown to increase submucosal gland secretions in non-CF airways, it is an ineffective secretagogue in CF airways [161]. Of note, increased CGRP content has been found in the airway submucosal glands of humans with $\mathrm{CF}$, as well as in mice, ferrets, and pigs with CF [161]. Taken together, these findings suggest that elevated CGRP in CF airways 
might be a compensatory mechanism to counter the lack of CGRP-mediated submucosal gland secretion. The authors also demonstrated an important role for CGRP in maintaining airway progenitor cells, which they speculated might be important for lung injury and repair in CF airways. Since CGRP participates in goblet cell hyperplasia and muc5AC induction in other disease models [39], it is possible that it is also involved in CF exacerbations, in which increased muc5AC has been noted [135].

With that said, it is difficult to predict whether inhibiting CGRP would be of significant benefit in CF, as one might anticipate mixed results (e.g. anti-inflammatory and vasodilatory properties versus involvement in mucus secretion). However, in the specific context of mucus, inhibition of CGRP might be of benefit in CF. Given the numerous CF animal models [162-165], preclinical studies examining this possibility are feasible.

\section{Neuropeptide Y (NPY)}

Neuropeptide Y (NPY) is a 36 aa peptide that belongs to the F- and Y-amide gene family [21, 166, 167]. NPY is synthesized in both the peripheral and central nervous systems [168]. NPY has been implicated in a wide variety of autoimmune and inflammatory diseases, including asthma and COPD [37, 167, 169-171]. It plays an important role in regulation of airway blood flow [37], smooth muscle contraction [172], immune cell/mast cell modulation $[167,169]$ and secretion output from submucosal glands [173, 174].

\section{Asthma}

The role of NPY in asthma remains unclear. For example, NPY has been associated with stress-induced exacerbation in asthma [175-177]. From those studies, it was suggested that NPY facilitated inflammation, as its concentrations correlated with the number of leukocytes and eosinophils in the bronchoalveolar lavage fluid. Similarly, NPY through activation of its $\mathrm{Y} 1$ receptor, was demonstrated to be critical for the development of allergic airway inflammation in mice [178]. Specifically, NPY and Y1 receptor knock-out mice showed decreased eosinophils in the bronchoalveolar lavage fluid, as well as decreased circulating immunoglobulin E (IgE) levels, compared to wild-type mice under allergic conditions [178]. Additional studies have found that loss of forkhead box protein P1 (Foxp)1 and forkhead box protein P4 (Foxp4) in mice can induce ectopic expression of NPY in airway epithelia, resulting in airway hyperresponsiveness [172]. Loss of Foxp1 and Foxp4 are also associated with ectopic expression of muc5AC in the airway [179]. Thus, although a direct regulation of muc5AC by NPY has not been established, the two parallel ectopic expressions, suggest an association. Consistent with that, elimination of pulmonary neuroendocrine cells in a murine model of asthma, decreased Npy gene expression, which was associated with decreased goblet cell hyperplasia [39]. However, in contrast to the aforementioned studies, Chanez and colleagues found decreased expression of NPY in the airway smooth muscle, but not in the epithelium, of people with asthma [180]. The authors proposed that NPY might be protective in the airway, and that loss of NPY might contribute to mucus hypersecretion. Similarly, Lacroix and Mosimann reported that pretreatment with NPY decreased nasal obstruction and mucus secretion in allergic rhinitis [181].

Although the NPY modulation has been explored in obesity, alcoholism, anxiety, depression, epilepsy and pain (reviewed in $[34,182,183]$ ), its potential benefit in asthma is largely unknown and unexplored. The numerous small molecules that have been developed to either potentiate or inhibit NPY receptor offer promise for investigating NPY signaling in asthma [182].

\section{COPD}

In COPD, it has been reported that NPY expression is decreased in the lung epithelium, glands and smooth muscle tissue [171], and the authors speculated that such changes might contribute to COPD pathogenesis. In mice, secondary tobacco smoke exposure, which is considered a risk factor for COPD [184], increases the density of the NPY nerve fibers in the tracheal smooth muscle [185]. The increase in NPY nerve fibers was associated with airway hyperresponsiveness, suggesting a potential pathological role for NPY. Others have shown that NPY stimulates secretion of interleukin 6 from airway fibroblasts [186]. An implication therefore was that NPY might contribute to diseases like COPD and asthma, in which elevated interleukin 6 has been found in the sputum [187]. Interestingly, reports suggest that the concentration of muc5AC is increased in the sputum of smokers [188]; thus, one speculation is that NPY expression is positively correlated with muc5AC. Unfortunately, no studies have directly examined the effects of NPY of submucosal gland secretion or goblet cell degranulation, in COPD.

To address the role of NPY in COPD, studies utilizing antagonists or agonists in animal models or humans with COPD are required. Additionally, although no studies have examined the effects of modulating NPY in COPD, the NPY antagonist BIBO 3304 has purported beneficial effects in pulmonary hypertension [189]. Therefore, it is possible that NPY modulation might be of benefit in some people with COPD, such as those that have pulmonary hypertension [130].

\section{Cystic fibrosis}

NPY was of interest in CF due to its close chromosomal location to CFTR [190]. However, a linkage between the 
loci of CFTR and NPY was excluded, and thus it was concluded that NPY likely played little role in CF pathogenesis. The only other study that has examined NPY in CF was conducted in the olfactory system, in which it was found that NPY was increased in the olfactory epithelium of CF mice [191]. The increased NPY was associated altered expression of specific microvilli proteins, and it was suggested that olfactory function might be affected. Thus, whether NPY is involved in CF pathogenesis, or modulates mucus secretion in $\mathrm{CF}$, remains unknown. The numerous CF animal models that develop airway disease similar to humans [162-165], as well as the multiple small molecules available that inhibit or potentiate NPY signaling [182, 189] offer ample opportunities to investigate the potential role of NPY in CF.

\section{Bombesins}

The bombesin-like peptide gene family is currently comprised of 5 peptides, originating from two genes - the gastrin-releasing peptide gene and the Neuromedin-B gene [21]. Bombesins are synthesized by both the nervous system [192] and by pulmonary neuroendocrine cells [193], as well as other tissues [194]. In mammals, two of the peptides have been cloned and characterized - the 27 aa gastrin-releasing peptide (GRP) and the 10 aa neuromedin $B(\mathrm{NMB})$, which act through their specific G-coupled receptors. For NMB, it is the subtype-1 receptor, and for GRP-27, it is the subtype-2 receptor [195-197]. Similar to the above described groups of neuropeptides, in humans, bombesin-like peptides (BLPs) have roles in many different physiological functions and pathological conditions - from glucose homeostasis to malignancies [195, 196, 198]. In the lungs, bombesins promote fetal lung development and maturation, as well as epithelial cell differentiation [37, 196]. They also play important roles in modulating airway physiology, including bronchoconstriction [199] and mucus secretion [200, 201], which we explore in more detail below.

\section{Asthma}

Recently, work by Sun and colleagues showed that the number of bombesin positive cells was increased in the airways of asthmatics [39]. Similarly, there have been several studies suggesting that exposure to tobacco products, which are triggers for asthma [202], increase components of BLP signaling in the lungs $[203,204]$. Interestingly, the increased expression of BLP signaling components persisted after smoking ceased, suggesting a long-term sensitivity to the proliferative effects of BLPs. Additionally, bronchopulmonary dysplasia, in which bombesins have been implicated [205], is considered a risk factor for asthma [206]. Evidence also suggests that bombesin receptor-activated protein regulates muc5AC hypersecretion through neutrophil elastase [207]; neutrophil elastase been implicated in goblet cell degranulation and mucus hypersecretion in a rodent model of asthma [208]. While we found no studies describing the effects of bombesins on submucosal gland activation and/or regulation of muc5B in asthma, its ability to modulate glycoprotein secretion from whole tracheas under normal physiological conditions [201] suggests a potential role for it in pathophysiological conditions. Finally, bombesin antagonists have not been explored in asthma; however, several small peptide antagonists have been developed [209]. For example, monoclonal antibodies targeted against GRP have shown promise for disrupting bombesin signaling in human airways. Thus, using these tools to disrupt bombesin signaling might shed new light onto the role that they play in asthma.

\section{COPD}

Bombesins have been implicated in COPD [193], with evidence suggesting that there is greater release of bombesins from COPD airways. Consistent with that, greater numbers of pulmonary neuroendocrine cells, which express bombesins, have been observed in the airways of people with COPD [158]. Potential consequences of increased bombesin signaling in COPD include inflammation [210], bronchoconstriction [211], and altered lung injury repair [212]. Additionally, bronchopulmonary dysplasia, in which bombesins have been implicated, may increase the risk for development of COPD later in life [213]. Although the role of bombesins in modulating mucus secretion or muc5AC/muc5B regulation in COPD is unknown, given that bombesins are increased in COPD [193] and muc5B is also increased [188], then it is possible that either a direct or indirect relationship between bombesin signaling and muc5B expression exists. Bombesin antagonists have not been explored in COPD, and therefore preclinical studies focused on inhibiting bombesins might be of particular interest.

\section{Cystic fibrosis}

Increased expression of bombesin in neuroendocrine cells of people with CF has been reported [214, 215]. While no mechanisms explaining those changes were suggested, additional studies have shown that neuroendocrine cells express CFTR [43]. An implication therefore is that CFTR function is directly linked to pulmonary neuroendocrine function. Thus, given the proposed importance of neuroendocrine cells in asthma and COPD, it is possible that an undiscovered yet important role of neuroendocrine cells, and by extension bombesins, in $\mathrm{CF}$ exists. This might be especially true given their proposed involvement in submucosal gland secretion [201], muc5AC expression [207], inflammation [210], bronchoconstriction [211], and lung injury repair [212]. Utilizing available bombesin antagonists to explore the role of bombesins in CF might open the door to new therapeutics. 


\section{Granins}

Granins are a large family of putative neuropeptides found in the secretory granules of the chromaffin adrenomedullary cells in adrenal glands [216]. They display structural features close to the classical neuropeptides. They are also synthesized by neurons and are co-stored and/or released together with other neuropeptides; however, currently they are not considered to be among the classical neuropeptides [21, 216].

There are 6 genes, 7 prepro-peptides and 14 active cleaved peptides in the granin family [21, 22]. The most characterized of these peptides are chromogranin A and its derivative - vasostatin; chromogranin B, secretogranin II, and secretoneurin. Although the functions of granins are still being elucidated, secretoneurin has been shown to induce mucus hypersecretion in human airway epithelial cell lines (16HBE and NCI-H292) and induce expression of muc5AC [36], suggesting a modulatory role in mucus secretion. Consistent with that, chromogranin A is more commonly found in epithelial mucinous tumors compared to nonmucinous tumors [217].

\section{Asthma}

Very few studies have examined granins in asthma. One study reported increased serum levels of chromogranin A in a mixed population of individuals, some of which had asthma [218]. The premise of that study was to identify biomarkers of pulmonary neuroendocrine tumors. Recently, Sui and colleagues reported increased chromogra$\operatorname{nin} \mathrm{A}$ in the airways of mice sensitized to ovalbumin [39]. Elshafie and colleagues also reported that increased wheezing in a patient with asthma was associated with increased serum levels of chromogranin A [219]. It has also been reported that secretogranin II (known as chromogranin C), is a potent chemoattractant for eosinophils [220], which play a critical role in asthma [221]. The proposed signaling molecule mediating eosinophil chemotaxis in response to secretogranin II was cyclic AMP [220].

While we were not able to find any studies examining the role of granins in mucus hypersecretion in asthma, secretoneurin induces mucus hypersecretion in non-asthmatic human airway cells [36]. Moreover, studies suggesting that secretoneurin is co-released with SubP and CGRP raise the possibility that secretoneurin is pro-inflammatory [222]. If true, then inhibiting secretoneurin might be particularly useful in asthma. Since the cell surface receptor secretoneurin and other granins are currently unknown (Fig. 2), future studies focused on identifying the receptor responsible for granin signaling are important [223].

\section{COPD}

Elevations in serum levels of chromogranin A have been reported in people with $\mathrm{COPD}$, and interestingly, the degree of obstruction correlated with chromogranin A concentrations [224]. The authors concluded that elevated chromogranin A reflected ongoing inflammatory processes in the airway. Circulating secretoneurin concentrations were also measured in people with COPD; compared to those with acute heart failure, people with COPD had decreased levels of secretoneurin [225]. It was proposed that secretoneurin was a "protective mediator" in people with heart failure. To the best of our knowledge, no studies have examined the potential contribution of granins in mucus-related phenotypes in COPD. However, it is possible that granins contribute to airway obstruction in COPD [224] through modulation of inflammation [222] and/or mucus secretion [36]. Additional studies are required to explore these possibilities.

\section{Cystic fibrosis}

Data indicate that pulmonary neuroendocrine cells expressing chromogranin A also express CFTR [226]. In neuroendocrine cells with diminished CFTR, neurosecretory properties were altered [226]. In follow-up study, Pan and colleagues determined that the number of pulmonary neuroendocrine cells were decreased in a mouse model of $\mathrm{CF}$, resulting in diminished oxygen sensing [67]. An implication from those studies was that loss of CFTR might impair the function of neuroendocrine cells that express chromogranin A, and possibly alter chromogranin A expression and/or signaling. While we were unable to find any additional studies that investigated granins in $\mathrm{CF}$, their potential for modulating inflammation [222] and mucus secretion [36] suggest that these neuropeptides might be of interest in CF airway disease.

\section{Conclusion}

Neuropeptides continue to be a source of insight and complexity when it comes to airway disease. Although significant progress has been made in understanding the contributions of some neuropeptides to asthma, COPD, and CF, their specific contributions to mucus obstruction and/or hypersecretion is, in many ways, unknown. Therefore, the field of neuropeptides and mucus secretion is fertile with questions. Below we highlight a few potential future directions that can be expanded upon to advance the field.

A greater emphasis needs to be placed on understanding the role that neuropeptides play in modulating mucus secretion in "normal" airways. More specifically, studies that delineate the effects of neuropeptides on submucosal gland secretion versus surface epithelial cell secretion need to be addressed. Techniques including (but not limited to) epithelial cells cultured at the air-liquid interface [227], as well as methods developed by Wine and colleagues [228] and/or Welsh and colleagues [229] are suitable for such studies. 
Additionally, given that muc5AC and muc5B expression profiles are affected in asthma [98], COPD [188], and CF [135], it is of interest to understand whether neuropeptides preferentially regulate expulsion of muc5AC and/or muc5B. Similarly, studies focused on determining whether neuropeptides influence the expression of muc5AC and/or muc5B at the protein or transcriptional levels will provide new insight regarding the regulation of mucins in both health and disease.

We found it surprising that there is relatively limited information available regarding the role that neuropeptides assume in regulating mucus secretion in asthma, COPD, and CF. Based upon our review of the literature available, more progress has been made in asthma compared to COPD or CF, but much work still remains. A few simple studies could narrow this knowledge gap. For example, using animal models or human samples derived from people with asthma, COPD, or CF, one can determine whether mucus secretion to a given neuropeptide is blunted or exaggerated. Similarly, examining how acute and/or repeated applications of neuropeptides affect expression of mucins (e.g., muc5AC, muc5B) in asthma, COPD, and CF would reveal a potentially causative role for neuropeptides in airway mucus phenotypes.

Additional studies might include the use of knockout or pharmacological approaches to assess the contribution of specific neuropeptides and/or their receptors to regulation of mucus secretion and expression. Moreover, a thorough investigation of the expression (both spatially and temporally) of neuropeptides and their receptors in the airway in both health and disease would provide additional insight regarding potential causative and/or modulatory roles in asthma, COPD, and CF.

Although it is difficult to select which neuropeptides are the most important and/or interesting to pursue, our review provides a road map to help guide researchers and clinicians. Clearly, species of interest will influence which neuropeptides can be readily studied, as the tools, models, and neuropeptides available vary according to species. In addition, there is less information regarding the signaling mechanisms of bombesins and granins. Thus, for these peptides, progress may require further efforts.

Mucus is a critical defensive mechanism [230]. Enhanced mucus secretion/production and/or abnormal mucus properties are associated with several airway diseases, as highlighted in this review. In order to find more specific targets and additional treatment options for people with asthma, COPD, or CF, a greater understanding of the regulation of mucus secretion by neuropeptides is undeniably important. We anticipate that future research aimed at investigating neuropeptide-mediated regulation of mucus secretion and expression will provide new insight into airway pathogenesis, as well as uncover new targets for therapeutic discovery.

\begin{abstract}
Abbreviations
aa: Amino acid; $\mathrm{BB}_{1}$ : Bombesin subtype-1 receptor; $\mathrm{BB}_{2}$ : Bombesin subtype-2 receptor; BLPs: Bombesin-like peptides; CAMP: Cyclic adenosine monophosphate; CF: Cystic fibrosis; CFTR: Cystic fibrosis conductance regulator; CGRP: Calcitonin gene-related peptide; DAG: Diacylglycerol; EK: Endokinins; FEV $_{1}$ : Forced expiratory volume; Foxp1: Forkhead box protein P1; Foxp4: Forkhead box protein P4; GABA: Gamma-Aminobutyric acid; GRP: Gastrin-releasing peptide; HK-1: Hemokinin 1; IgE: Immunoglobulin E; IP3: Inositol 1,4,5-trisphosphate; LAD2: Leukocyte adhesion deficiency-2; muc5AC: Mucin5AC; muc5B: Mucin5B; NK1: Neurokinin 1; NK2: Neurokinin 2; NK3: Neurokinin 3; NKA: Neurokinin A; NKB: Neurokinin B; NMB: Neuromedin B; NPY: Neuropeptide Y; OVA: Ovalbumin; PHM-27: Peptide histidine methionine 27; PHV-42: Peptide histidine methionine 42; RAMP1: Receptor activity modifying protein 1; RAMP2: Receptor activity modifying protein 2; SubP: Substance P; TAC1: Preprotachykinin A; TAC3: Preprotachykinin B;

TAC4: Preprotachykinin C; VIP: Vasoactive intestinal Peptide;

VPAC1: Vasoactive intestinal peptide receptor 1; VPAC2: Vasoactive intestinal peptide receptor 2
\end{abstract}

\section{Acknowledgements}

We thank Kevin Vogt for helpful assistance in the preparation of this manuscript.

\section{Funding}

ROOHL119560-03 (PI, LRR) and 10T2TR001983-01 (Co-I, LRR).

Availability of data and materials

All data generated or analysed during this study are included in this published article.

\section{Authors' contributions}

LRR and KRA read and interpreted available literature for the review. LRR and KRA generated tables and figures. LRR and KRA wrote and edited the manuscript. Both authors read and approved the final manuscript.

Ethics approval and consent to participate

Not applicable.

\section{Consent for publication \\ Not applicable.}

\section{Competing interests}

The authors declare that they have no competing interests.

\section{Publisher's Note}

Springer Nature remains neutral with regard to jurisdictional claims in published maps and institutional affiliations.

Received: 13 May 2018 Accepted: 13 July 2018

Published online: 06 August 2018

\section{References}

1. Summary tables of mortality estimates by cause, age and sex, globally and by region, 2000-2015 [http://www.who.int/entity/healthinfo/global_ burden_disease/GHE2015_Deaths_Global_2000_2015.xls?ua=1].

2. Cohn L. Mucus in chronic airway diseases: sorting out the sticky details. J Clin Invest. 2006;116:306-8.

3. Lai H, Rogers DF. New pharmacotherapy for airway mucus hypersecretion in asthma and COPD: targeting intracellular signaling pathways. J Aerosol Med Pulm Drug Deliv. 2010;23:219-31.

4. Livraghi-Butrico A, Grubb BR, Wilkinson KJ, Volmer AS, Burns KA, Evans CM, O'Neal WK, Boucher RC. Contribution of mucus concentration and secreted mucins Muc5ac and Muc5b to the pathogenesis of muco-obstructive lung disease. Mucosal Immunol. 2017;10:829.

5. Dunican EM, Elicker BM, Gierada DS, Nagle SK, Schiebler ML, Newell JD, Raymond WW, Lachowicz-Scroggins ME, Di Maio S, Hoffman EA, et al. Mucus plugs in patients with asthma linked to eosinophilia and airflow obstruction. J Clin Invest. 2018;128:997-1009.

6. Hartl D, Gaggar A, Bruscia E, Hector A, Marcos V, Jung A, Greene C, McElvaney G, Mall M, Döring G. Innate immunity in cystic fibrosis lung disease. J Cyst Fibros. 2012;11:363-82. 
7. Mall MA. Unplugging mucus in cystic fibrosis and chronic obstructive pulmonary disease. Ann Am Thorac Soc. 2016;13(2):S177-85.

8. Kang JW, Lee YH, Kang MJ, Lee HJ, Oh R, Min HJ, Namkung W, Choi JY, Lee SN, Kim CH, et al. Synergistic mucus secretion by histamine and IL-4 through TMEM16A in airway epithelium. Am J Physiol Lung Cell Mol Physiol. 2017;313: L466-76.

9. Gorrieri G, Scudieri P, Caci E, Schiavon M, Tomati V, Sirci F, Napolitano F, Carrella D, Gianotti A, Musante I, et al. Goblet cell hyperplasia requires high bicarbonate transport to support mucin release. Sci Rep. 2016;6:36016.

10. Zhou-Suckow Z, Duerr J, Hagner M, Agrawal R, Mall MA. Airway mucus, inflammation and remodeling: emerging links in the pathogenesis of chronic lung diseases. Cell Tissue Res. 2017;367:537-50.

11. Quinton PM. Role of epithelial $\mathrm{HCO} 3(-)$ transport in mucin secretion: lessons from cystic fibrosis. Am J Physiol Cell Physiol. 2010;299:C1222-33.

12. Ghosh A, Boucher RC, Tarran R. Airway hydration and COPD. Cell Mol Life Sci. 2015;72:3637-52.

13. Reznikov LR. Cystic fibrosis and the nervous system. Chest. 2017;151:1147-55.

14. Tokuyama K, Kuo HP, Rohde JA, Barnes PJ, Rogers DF. Neural control of goblet cell secretion in Guinea pig airways. Am J Phys. 1990;259:L108-15.

15. Rogers DF, Dewar A. Neural control of airway mucus secretion. Biomed Pharmacother. 1990;44:447-53.

16. Rogers DF, Alton EW, Dewar A, Lethem MI, Barnes PJ. Impaired stimulusevoked mucus secretion in cystic fibrosis bronchi. Exp Lung Res. 1993;19:37-53.

17. Rogers DF. Motor control of airway goblet cells and glands. Respir Physiol. 2001;125:129-44.

18. Rogers DF. Airway mucus hypersecretion in asthma: an undervalued pathology? Curr Opin Pharmacol. 2004;4:241-50.

19. Wine JJ. Parasympathetic control of airway submucosal glands: central reflexes and the airway intrinsic nervous system. Auton Neurosci. 2007;133:35-54.

20. Williams OW, Sharafkhaneh A, Kim V, Dickey BF, Evans CM. Airway mucus: from production to secretion. Am J Respir Cell Mol Biol. 2006;34:527-36.

21. Burbach JP. What are neuropeptides? Methods Mol Biol. 2011;789:1-36.

22. Burbach JP. Neuropeptides from concept to online database www. neuropeptides.nl. Eur J Pharmacol. 2010;626:27-48.

23. Merighi A, Salio C, Ferrini F, Lossi L. Neuromodulatory function of neuropeptides in the normal CNS. J Chem Neuroanat. 2011:42:276-87.

24. Coles SJ, Bhaskar KR, O'Sullivan DD, Neill KH, Reid LM. Airway mucus: composition and regulation of its secretion by neuropeptides in vitro. CIBA Found Symp. 1984;109:40-60.

25. Billington CK, Penn RB. Signaling and regulation of G protein-coupled receptors in airway smooth muscle. Respir Res. 2003;4:2.

26. Deshpande DA, Penn RB. Targeting G protein-coupled receptor signaling in asthma. Cell Signal. 2006;18:2105-20.

27. Bradley SJ, Wiegman CH, Iglesias MM, Kong KC, Butcher AJ, Plouffe B, Goupil E, Bourgognon JM, Macedo-Hatch T, LeGouill C, et al. Mapping physiological $\mathrm{G}$ protein-coupled receptor signaling pathways reveals a role for receptor phosphorylation in airway contraction. Proc Natl Acad Sci U S A. 2016;113:4524-9.

28. De Swert KO, Joos GF. Extending the understanding of sensory neuropeptides. Eur J Pharmacol. 2006;533:171-81.

29. Joos GF, De Swert KO, Pauwels RA. Airway inflammation and tachykinins: prospects for the development of tachykinin receptor antagonists. Eur J Pharmacol. 2001;429:239-50.

30. Groneberg DA, Rabe KF, Fischer A. Novel concepts of neuropeptide-based drug therapy: vasoactive intestinal polypeptide and its receptors. Eur J Pharmacol. 2006;533:182-94.

31. McLatchie LM, Fraser NJ, Main MJ, Wise A, Brown J, Thompson N, Solari R, Lee MG, Foord SM. RAMPs regulate the transport and ligand specificity of the calcitonin-receptor-like receptor. Nature. 1998;393:333-9

32. Balasubramaniam AA. Neuropeptide $Y$ family of hormones: receptor subtypes and antagonists. Peptides. 1997;18:445-57.

33. Pedragosa-Badia X, Stichel J, Beck-Sickinger AG. Neuropeptide $Y$ receptors: how to get subtype selectivity. Front Endocrinol (Lausanne). 2013:4:5.

34. Yi M, Li H, Wu Z, Yan J, Liu Q, Ou C, Chen M. A promising therapeutic target for metabolic diseases: neuropeptide $Y$ receptors in humans. Cell Physiol Biochem. 2018;45:88-107.

35. Jensen RT, Battey JF, Spindel ER, Benya RV. International Union of Pharmacology. LXVIII. Mammalian bombesin receptors: nomenclature, distribution, pharmacology, signaling, and functions in normal and disease states. Pharmacol Rev. 2008;60:1-42.
36. Xu R, Li Q, Zhou J, Zhou X, Perelman JM, Kolosov VP. Secretoneurin induces airway mucus hypersecretion by enhancing the binding of EGF to NRP1. Cell Physiol Biochem. 2014;33:446-56.

37. Barnes PJ, Rodger IW, Thomson NC. Asthma, basic mechanisms and clinical management. 3rd ed. London: San Diego Academic Press; 1998.

38. Branchfield K, Nantie L, Verheyden JM, Sui P, Wienhold MD, Sun X. Pulmonary neuroendocrine cells function as airway sensors to control lung immune response. Science. 2016;351:707-10.

39. Sui P, Wiesner DL, Xu J, Zhang Y, Lee J, Van Dyken S, Lashua A, Yu C, Klein BS, Locksley RM, et al. Pulmonary neuroendocrine cells amplify allergic asthma responses. Science. 2018;360(6393):eaan8546.

40. Pilmane M, Luts A, Sundler F. Changes in neuroendocrine elements in bronchial mucosa in chronic lung disease in adults. Thorax. 1995;50:551-4.

41. Cutz $E$, Yeger $H$, Pan J. Pulmonary neuroendocrine cell system in pediatric lung disease-recent advances. Pediatr Dev Pathol. 2007;10:419-35.

42. Pan J, Copland I, Post M, Yeger H, Cutz E. Mechanical stretch-induced serotonin release from pulmonary neuroendocrine cells: implications for lung development. Am J Physiol Lung Cell Mol Physiol. 2006;290:L185-93.

43. Yeger H, Pan J, Fu XW, Bear C, Cutz E. Expression of CFTR and Cl(-) conductances in cells of pulmonary neuroepithelial bodies. Am J Physiol Lung Cell Mol Physiol. 2001:281:L713-21.

44. Weichselbaum M, Sparrow MP, Hamilton EJ, Thompson PJ, Knight DA. A confocal microscopic study of solitary pulmonary neuroendocrine cells in human airway epithelium. Respir Res. 2005;6:115.

45. Soler X, Ramsdell JW. Are asthma and COPD a continuum of the same disease? J Allergy Clin Immunol Pract. 2015;3:489-95. quiz 496-487

46. GINA. Global Strategy for Asthma Management and Prevention. Global Initiative for Asthma (GINA); 2017. p. 2017.

47. McCracken JL, Veeranki SP, Ameredes BT, Calhoun WJ. Diagnosis and Management of Asthma in adults: a review. JAMA. 2017;318:279-90.

48. Lachowicz-Scroggins ME, Yuan S, Kerr SC, Dunican EM, Yu M, Carrington SD, Fahy JV. Abnormalities in MUC5AC and MUC5B protein in airway mucus in asthma. Am J Respir Crit Care Med. 2016;194:1296-9.

49. Wills-Karp M, Luyimbazi J, Xu X, Schofield B, Neben TY, Karp CL, Donaldson DD. Interleukin-13: central mediator of allergic asthma. Science. 1998;282:2258-61.

50. Mazzone SB, Undem BJ. Vagal afferent innervation of the Airways in Health and Disease. Physiol Rev. 2016;96:975-1024.

51. Talbot S, Abdulnour RE, Burkett PR, Lee S, Cronin SJ, Pascal MA, Laedermann C, Foster SL, Tran JV, Lai N, et al. Silencing nociceptor neurons reduces allergic airway inflammation. Neuron. 2015;87:341-54.

52. Fryer $A D$, Jacoby $D B$. Parainfluenza virus infection damages inhibitory $M 2$ muscarinic receptors on pulmonary parasympathetic nerves in the Guineapig. Br J Pharmacol. 1991;102:267-71

53. Aven L, Paez-Cortez J, Achey R, Krishnan R, Ram-Mohan S, Cruikshank WW, Fine A, Ai X. An NT4/TrkB-dependent increase in innervation links early-life allergen exposure to persistent airway hyperreactivity. FASEB J. 2014:28:897-907.

54. Hikichi M, Hashimoto S, Gon Y. Asthma and COPD overlap pathophysiology of ACO. Allergol Int. 2018:67:179-86.

55. Shaikh M, Sood RG, Sarkar M, Thakur V. Quantitative computed tomography (CT) assessment of emphysema in patients with severe chronic obstructive pulmonary disease (COPD) and its correlation with age, sex, pulmonary function tests, BMl, smoking, and biomass exposure. Pol J Radiol. 2017:82:760-6.

56. Dransfield MT, Wilhelm AM, Flanagan B, Courville C, Tidwell SL, Raju SV, Gaggar A, Steele C, Tang LP, Liu B, Rowe SM. Acquired cystic fibrosis transmembrane conductance regulator dysfunction in the lower airways in COPD. Chest. 2013;144:498-506.

57. Ramos FL, Krahnke JS, Kim V. Clinical issues of mucus accumulation in COPD. Int J Chron Obstruct Pulmon Dis. 2014:9:139-50.

58. Yamada $\mathrm{M}$, Ichinose $\mathrm{M}$. The cholinergic anti-inflammatory pathway: an innovative treatment strategy for respiratory diseases and their comorbidities. Curr Opin Pharmacol. 2018;40:18-25.

59. van Gestel AJ, Steier J. Autonomic dysfunction in patients with chronic obstructive pulmonary disease (COPD). J Thorac Dis. 2010;2:215-22.

60. Stewart AG, Marsh F, Waterhouse JC, Howard P. Autonomic nerve dysfunction in COPD as assessed by the acetylcholine sweat-spot test. Eur Respir J. 1994;7:1090-5.

61. Audrit KJ, Delventhal L, Aydin O, Nassenstein C. The nervous system of airways and its remodeling in inflammatory lung diseases. Cell Tissue Res. 2017;367:571-90. 
62. Smolonska J, Koppelman GH, Wijmenga C, Vonk JM, Zanen P, Bruinenberg M, Curjuric I, Imboden M, Thun GA, Franke L, et al. Common genes underlying asthma and COPD? Genome-wide analysis on the Dutch hypothesis. Eur Respir J. 2014;44:860-72.

63. Rommens JM, lannuzzi MC, Kerem B, Drumm ML, Melmer G, Dean M, Rozmahel R, Cole JL, Kennedy D, Hidaka N, et al. Identification of the cystic fibrosis gene: chromosome walking and jumping. Science. 1989;245:1059-65.

64. Stoltz DA, Meyerholz DK, Welsh MJ. Origins of cystic fibrosis lung disease. N Engl J Med. 2015;372:351-62.

65. Boucher RC. New concepts of the pathogenesis of cystic fibrosis lung disease. Eur Respir J. 2004;23:146-58.

66. Reznikov LR, Dong Q, Chen JH, Moninger TO, Park JM, Zhang Y, Du J, Hildebrand MS, Smith RJ, Randak CO, et al. CFTR-deficient pigs display peripheral nervous system defects at birth. Proc Natl Acad Sci U S A. 2013;110:3083-8.

67. Pan J, Luk C, Kent G, Cutz E, Yeger H. Pulmonary neuroendocrine cells, airway innervation, and smooth muscle are altered in Cftr null mice. Am J Respir Cell Mol Biol. 2006;35:320-6.

68. Davis PB, Kaliner M. Autonomic nervous system abnormalities in cystic fibrosis. J Chronic Dis. 1983;36:269-78.

69. Zhang Y, Lu L, Furlonger C, Wu GE, Paige CJ. Hemokinin is a hematopoieticspecific tachykinin that regulates B lymphopoiesis. Nat Immunol. 2000;1:392-7.

70. Steinhoff MS, von Mentzer B, Geppetti P, Pothoulakis C, Bunnett NW. Tachykinins and their receptors: contributions to physiological control and the mechanisms of disease. Physiol Rev. 2014;94:265-301.

71. Chuaychoo B, Hunter DD, Myers AC, Kollarik M, Undem BJ. Allergen-induced substance $P$ synthesis in large-diameter sensory neurons innervating the lungs. J Allergy Clin Immunol. 2005;116:325-31.

72. Naline E, Devillier P, Drapeau G, Toty L, Bakdach H, Regoli D, Advenier C. Characterization of neurokinin effects and receptor selectivity in human isolated bronchi. Am Rev Respir Dis. 1989;140: 679-86.

73. Fuller RW, Maxwell DL, Dixon CM, McGregor GP, Barnes VF, Bloom SR, Barnes PJ. Effect of substance $P$ on cardiovascular and respiratory function in subjects. J Appl Physiol (1985). 1987;62:1473-9.

74. FROSSARD N, BARNES P. Effect of tachykinins in small human airways. Neuropeptides. 1991;19:157-61

75. Lundberg JM, Martling CR, Saria A. Substance $P$ and capsaicin-induced contraction of human bronchi. Acta Physiol Scand. 1983;119:49-53.

76. Choi JY, Khansaheb M, Joo NS, Krouse ME, Robbins RC, Weill D, Wine JJ. Substance $P$ stimulates human airway submucosal gland secretion mainly via a CFTR-dependent process. J Clin Invest. 2009;119:1189-200.

77. Bera MM, Lu B, Martin TR, Cui S, Rhein LM, Gerard C, Gerard NP. Th17 cytokines are critical for respiratory syncytial virus-associated airway hyperreponsiveness through regulation by complement $\mathrm{C} 3 \mathrm{a}$ and tachykinins. J Immunol. 2011;187:4245-55.

78. Goravanahally MP, Hubbs AF, Fedan JS, Kashon ML, Battelli LA, Mercer RR, Goldsmith WT, Jackson MC, Cumpston A, Frazer DG, Dey RD. Diacetyl increases sensory innervation and substance $P$ production in rat trachea. Toxicol Pathol. 2014;42:582-90.

79. Khansaheb M, Choi JY, Joo NS, Yang YM, Krouse M, Wine JJ. Properties of substance P-stimulated mucus secretion from porcine tracheal submucosal glands. Am J Physiol Lung Cell Mol Physiol. 2011;300:L370-9.

80. Phillips JE, Hey JA, Corboz MR. Tachykinin NK3 and NK1 receptor activation elicits secretion from porcine airway submucosal glands. Br J Pharmacol. 2003;138:254-60.

81. Chu HW, Kraft M, Krause JE, Rex MD, Martin RJ. Substance P and its receptor neurokinin 1 expression in asthmatic airways. J Allergy Clin Immunol. 2000;106: 713-22.

82. Tomaki M, Ichinose $M$, Miura M, Hirayama $Y$, Yamauchi H, Nakajima $N$, Shirato K. Elevated substance $P$ content in induced sputum from patients with asthma and patients with chronic bronchitis. Am J Respir Crit Care Med. 1995;151:613-7.

83. Reznikov LR, Meyerholz DK, Adam RJ, Abou Alaiwa M, Jaffer O, Michalski AS, Powers LS, Price MP, Stoltz DA, Welsh MJ. Acid-sensing Ion Channel 1a contributes to airway Hyperreactivity in mice. PLoS One. 2016;11:e0166089.

84. Hallstrand TS, Debley JS, Farin FM, Henderson WR. Role of MUC5AC in the pathogenesis of exercise-induced bronchoconstriction. J Allergy Clin Immunol. 2007;119:1092-8.

85. Ramalho R, Soares $R$, Couto N, Moreira A. Tachykinin receptors antagonism for asthma: a systematic review. BMC Pulm Med. 2011;11:41.
86. Van Schoor J, Joos GF, Chasson BL, Brouard RJ, Pauwels RA. The effect of the NK2 tachykinin receptor antagonist SR 48968 (saredutant) on neurokinin A-induced bronchoconstriction in asthmatics. Eur Respir J. 1998;12:17-23.

87. Boot JD, de Haas S, Tarasevych S, Roy C, Wang L, Amin D, Cohen J, Sterk PJ, Miller B, Paccaly A, et al. Effect of an NK1/NK2 receptor antagonist on airway responses and inflammation to allergen in asthma. Am J Respir Crit Care Med. 2007;175:450-7.

88. Pinter E, Pozsgai G, Hajna Z, Helyes Z, Szolcsanyi J. Neuropeptide receptors as potential drug targets in the treatment of inflammatory conditions. $\mathrm{Br}$ J Clin Pharmacol. 2014;77:5-20.

89. Tian L, Cai L, Kang J. Elevated substance P content in sputum and plasma in patients with COPD and its relationship with FEV1/FVC. Zhonghua Jie He He Hu Xi Za Zhi. 2000;23:138-40.

90. Boschetto P, Miotto D, Bononi I, Faggian D, Plebani M, Papi A, Creminon C, De Rosa E, Fabbri LM, Mapp CE. Sputum substance P and neurokinin a are reduced during exacerbations of chronic obstructive pulmonary disease. Pulm Pharmacol Ther. 2005;18:199-205.

91. Kuo HP, Rohde JA, Barnes PJ, Rogers DF. Cigarette smoke-induced airway goblet cell secretion: dose-dependent differential nerve activation. Am J Phys. 1992;263:L161-7.

92. Caramori G, Casolari P, Barczyk A, Durham AL, Di Stefano A, Adcock I. COPD immunopathology. Semin Immunopathol. 2016;38:497-515.

93. Global Initiative for Chronic Obstructive Lung Disease - Global Initiative for Chronic Obstructive Lung Disease - GOLD [https://goldcopd.org/wpcontent/uploads/2018/02/WMS-GOLD-2018-Feb-Final-to-print-v2.pdf]. Accessed 10 May 2018.

94. De Swert KO, Bracke KR, Demoor T, Brusselle GG, Joos GF. Role of the tachykinin NK1 receptor in a murine model of cigarette smokeinduced pulmonary inflammation. Respir Res. 2009;10:37.

95. Pedersen KE, Buckner CK, Meeker SN, Undem BJ. Pharmacological examination of the neurokinin-1 receptor mediating relaxation of human intralobar pulmonary artery. J Pharmacol Exp Ther. 2000;292:319-25.

96. Pelaia G, Vatrella A, Gallelli L, Renda T, Caputi M, Maselli R, Marsico SA. Biological targets for therapeutic interventions in COPD: clinical potential. Int J Chron Obstruct Pulmon Dis. 2006;1:321-34.

97. Joo NS, Cho HJ, Khansaheb M, Wine JJ. Hyposecretion of fluid from tracheal submucosal glands of CFTR-deficient pigs. J Clin Invest. 2010;120:3161-6.

98. Ordonez CL, Khashayar R, Wong HH, Ferrando R, Wu R, Hyde DM, Hotchkiss JA, Zhang Y, Novikov A, Dolganov G, Fahy JV. Mild and moderate asthma is associated with airway goblet cell hyperplasia and abnormalities in mucin gene expression. Am J Respir Crit Care Med. 2001;163:517-23.

99. Mizukami T, Tsunamura S. Some contributions to cancer control by the stimulation of the physiological protective power of the organism. Oncologia. 1962;15:312-23.

100. lanowski JP, Choi JY, Wine JJ, Hanrahan JW. Substance P stimulates CFTRdependent fluid secretion by mouse tracheal submucosal glands. Pflugers Arch. 2008;457:529-37.

101. O'Connor TM, O'Connell J, O'Brien DI, Goode T, Bredin CP, Shanahan F. The role of substance $P$ in inflammatory disease. J Cell Physiol. 2004;201:167-80.

102. Patacchini R, Lecci A, Holzer P, Maggi CA. Newly discovered tachykinins raise new questions about their peripheral roles and the tachykinin nomenclature. Trends Pharmacol Sci. 2004;25:1-3.

103. Borbély É, Helyes Z. Role of hemokinin-1 in health and disease. Neuropeptides. 2017;64:9-17.

104. Palma C. Tachykinins and their receptors in human malignancies. Curr Drug Targets. 2006;7:1043-52.

105. Wang W, Li Q, Zhang J, Wu H, Yin Y, Ge Q, Zhang Y. Hemokinin-1 activates the MAPK pathway and enhances $B$ cell proliferation and antibody production. J Immunol. 2010;184:3590-7.

106. Soltani A, Ewe YP, Lim ZS, Sohal SS, Reid D, Weston S, Wood-Baker R, Walters EH. Mast cells in COPD airways: relationship to bronchodilator responsiveness and angiogenesis. Eur Respir J. 2012;39:1361-7.

107. Kuzubova NA, Lebedeva ES, Titova ON, Fedin AN, Dvorakovskaya IV. Role of mast cells in bronchial contraction in nonallergic obstructive lung pathology. J Smooth Muscle Res. 2017;53:90-9.

108. Ballarin A, Bazzan E, Zenteno RH, Turato G, Baraldo S, Zanovello D, Mutti E, Hogg JC, Saetta M, Cosio MG. Mast cell infiltration discriminates between histopathological phenotypes of chronic obstructive pulmonary disease. Am J Respir Crit Care Med. 2012;186:233-9. 
109. Grassin-Delyle S, Naline E, Buenestado A, Risse PA, Sage E, Advenier C, Devillier P. Expression and function of human hemokinin-1 in human and Guinea pig airways. Respir Res. 2010;11:139.

110. Manorak W, Idahosa C, Gupta K, Roy S, Panettieri R, Ali H. Upregulation of mas-related $\mathrm{G}$ protein coupled receptor X2 in asthmatic lung mast cells and its activation by the novel neuropeptide hemokinin-1. Respir Res. 2018;19:1.

111. Delgado M, Ganea D. Vasoactive intestinal peptide: a neuropeptide with pleiotropic immune functions. Amino Acids. 2013;45:25-39.

112. Groneberg D, Springer J, Fischer A. Vasoactive intestinal polypeptide as mediator of asthma. Pulm Pharmacol Ther. 2001;14:391-401.

113. Kim JS, Okamoto K, Arima S, Rubin BK. Vasoactive intestinal peptide stimulates mucus secretion, but nitric oxide has no effect on mucus secretion in the ferret trachea. J Appl Physiol (1985). 2006;101:486-91.

114. BARNES P. AIRWAY NEUROPEPTIDES AND ASTHMA. Trends Pharmacol Sci. 1987;8:24-7.

115. Coles SJ, Said SI, Reid LM. Inhibition by vasoactive intestinal peptide of glycoconjugate and lysozyme secretion by human airways in vitro. Am Rev Respir Dis. 1981;124:531-6.

116. Ollerenshaw S, Jarvis D, Woolcock A, Sullivan C, Scheibner T. Absence of immunoreactive vasoactive intestinal polypeptide in tissue from the lungs of patients with asthma. N Engl J Med. 1989;320:1244-8.

117. Athari SS, Pourpak Z, Folkerts G, Garssen J, Moin M, Adcock IM, Movassaghi M, Ardestani MS, Moazzeni SM, Mortaz E. Conjugated alpha-alumina nanoparticle with vasoactive intestinal peptide as a Nano-drug in treatment of allergic asthma in mice. Eur J Pharmacol. 2016;791:811-20.

118. Ho JJ, Crawley S, Pan PL, Farrelly ER, Kim YS. Secretion of MUC5AC mucin from pancreatic cancer cells in response to forskolin and VIP. Biochem Biophys Res Commun. 2002;294:680-6.

119. Woodruff PG, Modrek B, Choy DF, Jia G, Abbas AR, Ellwanger A, Koth LL, Arron JR, Fahy JV. T-helper type 2-driven inflammation defines major subphenotypes of asthma. Am J Respir Crit Care Med. 2009;180:388-95.

120. Linden A, Hansson L, Andersson A, Palmqvist M, Arvidsson P, Lofdahl CG, Larsson P, Lotvall J. Bronchodilation by an inhaled VPAC(2) receptor agonist in patients with stable asthma. Thorax. 2003;58:217-21.

121. Wu D, Lee $D$, Sung YK. Prospect of vasoactive intestinal peptide therapy for COPD/PAH and asthma: a review. Respir Res. 2011;12:45.

122. Onoue S, Yamada S, Yajima T. Bioactive analogues and drug delivery systems of vasoactive intestinal peptide (VIP) for the treatment of asthma/ COPD. Peptides. 2007;28:1640-50

123. Paulis L, Rajkovicova R, Simko F. New developments in the pharmacological treatment of hypertension: dead-end or a glimmer at the horizon? Curr Hypertens Rep. 2015;17:557.

124. Mandal J, Roth M, Costa L, Boeck L, Rakic J, Scherr A, Tamm M, Stolz D. Vasoactive intestinal peptide for diagnosing exacerbation in chronic obstructive pulmonary disease. Respiration. 2015;90:357-68.

125. Bernhard Burian SA, Nadler B, Petkov V, Block LH. Inhaled vasoactive intestinal peptide (vip) improves the 6-minute walk test and quality of life in patients with copd: the vip/copd-trial. Chest. 2006;130(4):121S.

126. Kim V, Criner GJ. Chronic bronchitis and chronic obstructive pulmonary disease. Am J Respir Crit Care Med. 2013;187:228-37.

127. Lucchini RE, Facchini F, Turato G, Saetta M, Caramori G, Ciaccia A, Maestrelli P, Springall DR, Polak JM, Fabbri L, Mapp CE. Increased VIP-positive nerve fibers in the mucous glands of subjects with chronic bronchitis. Am J Respir Crit Care Med. 1997;156:1963-8

128. Miotto D, Boschetto P, Bononi I, Zeni E, Cavallesco G, Fabbri LM, Mapp CE. Vasoactive intestinal peptide receptors in the airways of smokers with chronic bronchitis. Eur Respir J. 2004;24:958-63.

129. Joo NS, Irokawa T, Wu JV, Robbins RC, Whyte RI, Wine JJ. Absent secretion to vasoactive intestinal peptide in cystic fibrosis airway glands. J Biol Chem. 2002:277:50710-5

130. Chaouat A, Naeije R, Weitzenblum E. Pulmonary hypertension in COPD. Eur Respir J. 2008:32:1371-85.

131. Sharma RK, Addis BJ, Jeffery PK. The distribution and density of airway vasoactive intestinal polypeptide (VIP) binding sites in cystic fibrosis and asthma. Pulm Pharmacol. 1995;8:91-6.

132. Derand R, Montoni A, Bulteau-Pignoux L, Janet T, Moreau B, Muller JM, Beca F. Activation of VPAC1 receptors by VIP and PACAP-27 in human bronchial epithelial cells induces CFTR-dependent chloride secretion. Br J Pharmacol. 2004;141:698-708.
133. Alcolado NG, Conrad DJ, Poroca D, Li M, Alshafie W, Chappe FG, Pelis RM, Anin $\mathrm{Y}, \mathrm{Xu} Z \mathrm{Z}$, Hamidi S, et al. Cystic fibrosis transmembrane conductance regulator dysfunction in VIP knockout mice. Am J Physiol Cell Physiol. 2014;307:C195-207.

134. Bonser LR, Erle DJ. Airway mucus and asthma: the role of MUC5AC and MUC5B. J Clin Med. 2017;6:E112.

135. Henke MO, John G, Germann M, Lindemann H, Rubin BK. MUC5AC and MUC5B mucins increase in cystic fibrosis airway secretions during pulmonary exacerbation. Am J Respir Crit Care Med. 2007;175:816-21.

136. Amara SG, Jonas V, Rosenfeld MG, Ong ES, Evans RM. Alternative RNA processing in calcitonin gene expression generates mRNAs encoding different polypeptide products. Nature. 1982;298:240-4.

137. Rosenfeld MG, Mermod JJ, Amara SG, Swanson LW, Sawchenko PE, Rivier J, Vale WW, Evans RM. Production of a novel neuropeptide encoded by the calcitonin gene via tissue-specific RNA processing. Nature. 1983;304:129-35.

138. Springer J, Geppetti P, Fischer A, Groneberg DA. Calcitonin gene-related peptide as inflammatory mediator. Pulm Pharmacol Ther. 2003;16:121-30.

139. Qing X, Svaren J, Keith IM. mRNA expression of novel CGRP1 receptors and their activity-modifying proteins in hypoxic rat lung. Am J Physiol Lung Cell Mol Physiol. 2001;280:L547-54.

140. Messlinger K. The big CGRP flood - sources, sinks and signalling sites in the trigeminovascular system. J Headache Pain. 2018;19:22

141. Keith IM, Pelto-Huikko M, Schalling M, Hökfelt T. Calcitonin gene-related peptide and its mRNA in pulmonary neuroendocrine cells and ganglia. Histochemistry. 1991;96:311-5.

142. Kuo HP, Rohde JA, Tokuyama K, Barnes PJ, Rogers DF. Capsaicin and sensory neuropeptide stimulation of goblet cell secretion in Guinea-pig trachea. J Physiol. 1990;431:629-41.

143. Webber SE, Lim JC, Widdicombe JG. The effects of calcitonin gene-related peptide on submucosal gland secretion and epithelial albumin transport in the ferret trachea in vitro. Br J Pharmacol. 1991;102:79-84.

144. Tschirhart E, Bertrand C, Theodorsson E, Landry Y. Evidence for the involvement of calcitonin gene-related peptide in the epitheliumdependent contraction of Guinea-pig trachea in response to capsaicin. Naunyn Schmiedeberg's Arch Pharmacol. 1990;342:177-81.

145. Kanemura T, Tamaoki J, Horii S, Sakai N, Kobayashi K, Isono K, Takeuchi S, Takizawa T. Calcitonin gene-related peptide augments parasympathetic contraction of rabbit tracheal smooth muscle in vitro. Agents Actions. 1990; 31:219-24.

146. Barnes PJ. Mediators and asthma. Br J Hosp Med. 1985;34:339-44.

147. BARNES P. AIRWAY NEUROPEPTIDES AND ASTHMA. Regul Pept. 1988;22:390.

148. Kay AB, Ali FR, Heaney LG, Benyahia F, Soh CP, Renz H, Lee TH, Larche M. Airway expression of calcitonin gene-related peptide in T-cell peptideinduced late asthmatic reactions in atopics. Allergy. 2007;62:495-503.

149. Tan YR, Yang T, Liu SP, Xiang Y, Qu F, Liu HJ, Qin XQ. Pulmonary peptidergic innervation remodeling and development of airway hyperresponsiveness induced by RSV persistent infection. Peptides. 2008:29:47-56.

150. Larson SD, Plopper CG, Baker G, Tarkington BK, Decile KC, Pinkerton K, Mansoor JK, Hyde DM, Schelegle ES. Proximal airway mucous cells of ovalbumin-sensitized and -challenged Brown Norway rats accumulate the neuropeptide calcitonin gene-related peptide. Am J Physiol Lung Cell Mo Physiol. 2004;287:L286-95.

151. Tso AR, Goadsby PJ. Anti-CGRP monoclonal antibodies: the next era of migraine prevention? Curr Treat Options Neurol. 2017;19:27.

152. Durham PL, Vause CV. Calcitonin gene-related peptide (CGRP) receptor antagonists in the treatment of migraine. CNS Drugs. 2010;24:539-48.

153. Bigal ME, Walter S, Bronson M, Alibhoy A, Escandon R. Cardiovascular and hemodynamic parameters in women following prolonged CGRP inhibition using LBR-101, a monoclonal antibody against CGRP. Cephalalgia. 2014;34: 968-76.

154. Walter S, Alibhoy A, Escandon R, Bigal ME. Evaluation of cardiovascular parameters in cynomolgus monkeys following IV administration of LBR-101, a monoclonal antibody against calcitonin gene-related peptide. MAbs. 2014 6:871-8.

155. González-Hernández A, Marichal-Cancino BA, Lozano-Cuenca J, LópezCanales JS, Muñoz-Islas E, Ramírez-Rosas MB, Villalón CM. Heteroreceptors modulating CGRP release at neurovascular junction: potential therapeutic implications on some vascular-related diseases. Biomed Res Int. 2016;2016: 2056786.

156. Depre C, Antalik L, Starling A, Koren M, Eisele O, Lenz RA, Mikol DD. A randomized, double-blind, placebo-controlled study to evaluate the effect 
of Erenumab on exercise time during a treadmill test in patients with stable angina. Headache. 2018;58:715-23.

157. Xu H, Zhao M, Wang X. Changes of calcitonin gene-related peptide content in induced sputum from patients with COPD and asthma. Zhonghua Jie He He Hu Xi Za Zhi. 1999;22:558-61.

158. Gu X, Karp PH, Brody SL, Pierce RA, Welsh MJ, Holtzman MJ, Ben-Shahar Y. Chemosensory functions for pulmonary neuroendocrine cells. Am J Respir Cell Mol Biol. 2014;50:637-46.

159. Zhang S, Loch AJ, Radtke F, Egan SE, Xu K. Jagged1 is the major regulator of notch-dependent cell fate in proximal airways. Dev Dyn. 2013;242:678-86.

160. Springer J, Amadesi S, Trevisani M, Harrison S, Dinh QT, McGregor GP, Fischer A, Geppetti P, Groneberg DA. Effects of alpha calcitonin generelated peptide in human bronchial smooth muscle and pulmonary artery. Regul Pept. 2004;118:127-34.

161. Xie W, Fisher JT, Lynch TJ, Luo M, Evans TI, Neff TL, Zhou W, Zhang Y, Ou Y, Bunnett NW, et al. CGRP induction in cystic fibrosis airways alters the submucosal gland progenitor cell niche in mice. J Clin Invest. 2011;121: 3144-58.

162. Sun X, Sui H, Fisher JT, Yan Z, Liu X, Cho HJ, Joo NS, Zhang Y, Zhou W, Yi Y, et al. Disease phenotype of a ferret CFTR-knockout model of cystic fibrosis. J Clin Invest. 2010:120:3149-60.

163. Rogers CS, Stoltz DA, Meyerholz DK, Ostedgaard LS, Rokhlina T, Taft PJ, Rogan MP, Pezzulo AA, Karp PH, Itani OA, et al. Disruption of the CFTR gene produces a model of cystic fibrosis in newborn pigs. Science. 2008;321: 1837-41.

164. Ostedgaard LS, Meyerholz DK, Chen JH, Pezzulo AA, Karp PH, Rokhlina T, Ernst SE, Hanfland RA, Reznikov LR, Ludwig PS, et al. The DeltaF508 mutation causes CFTR misprocessing and cystic fibrosis-like disease in pigs. Sci Transl Med. 2011;3:74ra24.

165. Tuggle KL, Birket SE, Cui X, Hong J, Warren J, Reid L, Chambers A, Ji D, Gamber K, Chu KK, et al. Characterization of defects in ion transport and tissue development in cystic fibrosis transmembrane conductance regulator (CFTR)-knockout rats. PLoS One. 2014;9:e91253.

166. Tatemoto K. Neuropeptide Y: complete amino acid sequence of the brain peptide. Proc Natl Acad Sci U S A. 1982;79:5485-9.

167. Groneberg DA, Folkerts G, Peiser C, Chung KF, Fischer A. Neuropeptide Y (NPY). Pulm Pharmacol Ther. 2004;17:173-80.

168. Cougnon N, Hudspith MJ, Munglani R. The therapeutic potential of neuropeptide $Y$ in central nervous system disorders with special reference to pain and sympathetically maintained pain. Expert Opin Investig Drugs. 1997;6:759-69.

169. Wheway J, Herzog H, Mackay F. NPY and receptors in immune and inflammatory diseases. Curr Top Med Chem. 2007;7:1743-52.

170. Makinde TO, Steininger R, Agrawal DK. NPY and NPY receptors in airway structural and inflammatory cells in allergic asthma. Exp Mol Pathol. 2013;94:45-50.

171. Vatrella A, Montagnani S, Calabrese C, Parrella R, Pelaia G, Biscione GL, Corcione N, Marsico SA, Guerra G. Neuropeptide expression in the airways of COPD patients and smokers with normal lung function. J Biol Regul Homeost Agents. 2010;24:425-32.

172. Li S, Koziol-White C, Jude J, Jiang M, Zhao H, Cao G, Yoo E, Jester W, Morley MP, Zhou S, et al. Epithelium-generated neuropeptide $Y$ induces smooth muscle contraction to promote airway hyperresponsiveness. J Clin Invest. 2016;126:1978-82.

173. Webber SE. The effects of peptide histidine isoleucine and neuropeptide $\mathrm{Y}$ on mucus volume output from the ferret trachea. $\mathrm{Br} J$ Pharmacol. 1988:95:49-54

174. Merten MD, Figarella C. Neuropeptide $Y$ and norepinephrine cooperatively inhibit human tracheal gland cell secretion. Am J Phys. 1994;266:L513-8.

175. Dahlof C, Dahlof P, Lundberg JM, Strombom U. Elevated plasma concentration of neuropeptide $Y$ and low level of circulating adrenaline in elderly asthmatics during rest and acute severe asthma. Pulm Pharmacol. 1988;1:3-6.

176. Lu Y, Ho R, Lim TK, Kuan WS, Goh DY, Mahadevan M, Sim TB, Van Bever HP, Larbi A, Ng TP. Neuropeptide Y may mediate psychological stress and enhance TH2 inflammatory response in asthma. J Allergy Clin Immunol. 2015;135:1061-1063.e1064

177. Lu Y, Ho RC. An association between neuropeptide $Y$ levels and leukocyte subsets in stress-exacerbated asthmatic mice. Neuropeptides. 2016;57:53-8.

178. Macia L, Rao PT, Wheway J, Sierro F, Mackay F, Herzog H. Y1 signalling has a critical role in allergic airway inflammation. Immunol Cell Biol. 2011;89:882-8.
179. Li S, Wang Y, Zhang Y, Lu MM, DeMayo FJ, Dekker JD, Tucker PW, Morrisey EE. Foxp1/4 control epithelial cell fate during lung development and regeneration through regulation of anterior gradient 2. Development. 2012; 139:2500-9.

180. Chanez P, Springall D, Vignola AM, Moradoghi-Hattvani A, Polak JM, Godard $\mathrm{P}$, Bousquet J. Bronchial mucosal immunoreactivity of sensory neuropeptides in severe airway diseases. Am J Respir Crit Care Med. 1998; 158:985-90

181. Lacroix JS, Mosimann BL. Attenuation of allergen-evoked nasal responses by local pretreatment with exogenous neuropeptide $Y$ in atopic patients. J Allergy Clin Immunol. 1996;98:611-6.

182. Brothers SP, Wahlestedt C. Therapeutic potential of neuropeptide Y (NPY) receptor ligands. EMBO Mol Med. 2010;2:429-39.

183. Borbély E, Scheich B, Helyes Z. Neuropeptides in learning and memory. Neuropeptides. 2013;47:439-50.

184. Rab A, Rowe SM, Raju SV, Bebok Z, Matalon S, Collawn JF. Cigarette smoke and CFTR: implications in the pathogenesis of COPD. Am J Physiol Lung Cell Mol Physiol. 2013;305:L530-41.

185. Wu ZX, Benders KB, Hunter DD, Dey RD. Early postnatal exposure of mice to side-steam tobacco smoke increases neuropeptide $Y$ in lung. Am J Physiol Lung Cell Mol Physiol. 2012;302:L152-9.

186. Thangaratnarajah C, Dinger K, Vohlen C, Klaudt C, Nawabi J, Lopez Garcia E, Kwapiszewska G, Dobner J, Nusken KD, van Koningsbruggen-Rietschel S, et al. Novel role of NPY in neuroimmune interaction and lung growth after intrauterine growth restriction. Am J Physiol Lung Cell Mol Physiol. 2017; 313:L491-506.

187. Grubek-Jaworska H, Paplinska M, Hermanowicz-Salamon J, Bialek-Gosk K Dabrowska M, Grabczak E, Domagala-Kulawik J, Stepien J, Chazan R. IL-6 and IL-13 in induced sputum of COPD and asthma patients: correlation with respiratory tests. Respiration. 2012;84:101-7.

188. Kirkham S, Kolsum U, Rousseau K, Singh D, Vestbo J, Thornton DJ. MUC5B is the major mucin in the gel phase of sputum in chronic obstructive pulmonary disease. Am J Respir Crit Care Med. 2008;178:1033-9.

189. Crnkovic S, Egemnazarov B, Jain P, Seay U, Gattinger N, Marsh LM, Balint Z, Kovacs G, Ghanim B, Klepetko W, et al. NPY/Y(1) receptor-mediated vasoconstrictory and proliferative effects in pulmonary hypertension. $\mathrm{Br} J$ Pharmacol. 2014;171:3895-907.

190. Meisler MH, Spence JE, Dixon JE, Caldwell RM, Minth CD, Beaudet AL. Exclusion of close linkage between the loci for cystic fibrosis and neuropeptide Y on human chromosome 7. Cytogenet Cell Genet. 1987; 44:175-6.

191. Pfister S, Weber T, Hartig W, Schwerdel C, Elsaesser R, Knuesel I, Fritschy JM. Novel role of cystic fibrosis transmembrane conductance regulator in maintaining adult mouse olfactory neuronal homeostasis. J Comp Neurol. 2015:523:406-30

192. Fleming MS, Ramos D, Han SB, Zhao J, Son YJ, Luo W. The majority of dorsal spinal cord gastrin releasing peptide is synthesized locally whereas neuromedin B is highly expressed in pain- and itch-sensing somatosensory neurons. Mol Pain. 2012;8:52.

193. Siegfried JM, Guentert PJ, Gaither AL. Effects of bombesin and gastrinreleasing peptide on human bronchial epithelial cells from a series of donors: individual variation and modulation by bombesin analogs. Anat Rec. 1993;236:241-7.

194. Miller YE. Bombesin-like peptides: from frog skin to human lung. Am J Respir Cell Mol Biol. 1990;3:189-90.

195. Gonzalez N, Moody TW, Igarashi H, Ito T, Jensen RT. Bombesin-related peptides and their receptors: recent advances in their role in physiology and disease states. Curr Opin Endocrinol Diabetes Obes. 2008;15:58-64.

196. Qin XQ, Qu XP. Extraintestinal roles of bombesin-like peptides and their receptors: lung. Curr Opin Endocrinol Diabetes Obes. 2013;20:22-6.

197. Ramos-Alvarez I, Moreno P, Mantey SA, Nakamura T, Nuche-Berenguer B, Moody TW, Coy DH, Jensen RT. Insights into bombesin receptors and ligands: highlighting recent advances. Peptides. 2015;72:128-44.

198. Guo M, Qu X, Qin XQ. Bombesin-like peptides and their receptors: recent findings in pharmacology and physiology. Curr Opin Endocrinol Diabetes Obes. 2015;22:3-8

199. Lach E, Haddad EB, Gies JP. Contractile effect of bombesin on Guinea pig lung in vitro: involvement of gastrin-releasing peptide-preferring receptors. Am J Phys. 1993;264:L80-6.

200. Baraniuk JN, Lundgren JD, Shelhamer JH, Kaliner MA. Gastrin releasing peptide (GRP) binding sites in human bronchi. Neuropeptides. 1992;21:81-4. 
201. Lundgren JD, Baraniuk JN, Ostrowski NL, Kaliner MA, Shelhamer JH. Gastrinreleasing peptide stimulates glycoconjugate release from feline trachea. Am J Phys. 1990;258:L68-74.

202. Eisner MD, Klein J, Hammond SK, Koren G, Lactao G, Iribarren C. Directly measured second hand smoke exposure and asthma health outcomes. Thorax. 2005;60:814-21.

203. Siegfried JM, DeMichele MA, Hunt JD, Davis AG, Vohra KP, Pilewski JM. Expression of mRNA for gastrin-releasing peptide receptor by human bronchial epithelial cells. Association with prolonged tobacco exposure and responsiveness to bombesin-like peptides. Am J Respir Crit Care Med. 1997; 156:358-66.

204. Shriver SP, Bourdeau HA, Gubish CT, Tirpak DL, Davis AL, Luketich JD, Siegfried JM. Sex-specific expression of gastrin-releasing peptide receptor: relationship to smoking history and risk of lung cancer. J Natl Cancer Inst. 2000;92:24-33.

205. Subramaniam M, Bausch C, Twomey A, Andreeva S, Yoder BA, Chang L, Crapo JD, Pierce RA, Cuttitta F, Sunday ME. Bombesin-like peptides modulate alveolarization and angiogenesis in bronchopulmonary dysplasia. Am J Respir Crit Care Med. 2007;176:902-12

206. Perez Tarazona S, Solano Galan P, Bartoll Alguacil E, Alfonso Diego J. Bronchopulmonary dysplasia as a risk factor for asthma in school children and adolescents: a systematic review. Allergol Immunopathol (Madr). 2018; 46:87-98.

207. Xu Q, Chen LX, Ran DH, Xie WY, Li Q, Zhou XD. Bombesin receptor-activated protein regulates neutrophil elastase-induced mucin5AC hypersecretion in human bronchial epithelial cells. Exp Cell Res. 2017;357:145-54.

208. Nadel JA, Takeyama K, Agusti C. Role of neutrophil elastase in hypersecretion in asthma. Eur Respir J. 1999;13:190-6.

209. Hohla F, Schally AV. Targeting gastrin releasing peptide receptors: new options for the therapy and diagnosis of cancer. Cell Cycle. 2010;9:1738-41.

210. Lemaire I. Bombesin-related peptides modulate interleukin-1 production by alveolar macrophages. Neuropeptides. 1991;20:217-23.

211. Belvisi MG, Stretton CD, Barnes PJ. Bombesin-induced bronchoconstriction in the Guinea pig: mode of action. J Pharmacol Exp Ther. 1991;258:36-41.

212. Kim JS, McKinnis VS, White SR. Migration of Guinea pig airway epithelial cells in response to bombesin analogues. Am J Respir Cell Mol Biol. 1997;16: 259-66.

213. Roos $A B$, Berg T, Nord M. A relationship between epithelial maturation, bronchopulmonary dysplasia, and chronic obstructive pulmonary disease. Pulm Med. 2012;2012:196194

214. Johnson DE, Wobken JD, Landrum BG. Changes in bombesin, calcitonin, and serotonin immunoreactive pulmonary neuroendocrine cells in cystic fibrosis and after prolonged mechanical ventilation. Am Rev Respir Dis. 1988:137:123-31.

215. Wolf $P$, Hall C, Kilbourn JP. Demonstration of calcitonin and calmodulin by immunoperoxidase in the cystic fibrosis lung. Chest. 1986;89:327-30.

216. Helle KB, Metz-Boutigue MH, Cerra MC, Angelone T. Chromogranins: from discovery to current times. Pflugers Arch. 2018:470:143-54.

217. Yajima N, Wada R, Yamagishi S, Mizukami H, Itabashi C, Yagihashi S. Immunohistochemical expressions of cytokeratins, mucin core proteins, p53, and neuroendocrine cell markers in epithelial neoplasm of appendix. Hum Pathol. 2005;36:1217-25

218. Al-Risi ES, Al-Essry FS, Mula-Abed WS. Chromogranin a as a biochemical marker for neuroendocrine tumors: a single center experience at Royal Hospital, Oman. Oman Med J. 2017;32:365-70.

219. Elshafie O, Nair J, Busaidi M, Riyami B, Hussein S, Woodhouse N. Chromogranin-a levels and refractory bronchospasm in interstitial lung disease: a preliminary report on the Favourable response to octreotide. British J Med Medical Res. 2015;7:705-10.

220. Dunzendorfer S, Schratzberger P, Reinisch N, Kahler CM, Wiedermann CJ. Secretoneurin, a novel neuropeptide, is a potent chemoattractant for human eosinophils. Blood. 1998;91:1527-32.

221. Douwes J, Gibson P, Pekkanen J, Pearce N. Non-eosinophilic asthma: importance and possible mechanisms. Thorax. 2002;57:643-8.

222. Kirchmair R, Marksteiner J, Troger J, Mahata SK, Mahata M, Donnerer J, Amann R, Fischer-Colbrie R, Winkler H, Saria A. Human and rat primary Cfibre afferents store and release secretoneurin, a novel neuropeptide. Eur J Neurosci. 1994;6:861-8

223. Zhao E, Basak A, Wong AO, Ko W, Chen A, Lopez GC, Grey CL, Canosa LF, Somoza GM, Chang JP, Trudeau VL. The secretogranin II-derived peptide secretoneurin stimulates luteinizing hormone secretion from gonadotrophs. Endocrinology. 2009;150:2273-82.

224. Sorhaug S, Langhammer A, Waldum HL, Hveem K, Steinshamn S. Increased serum levels of chromogranin a in male smokers with airway obstruction. Eur Respir J. 2006;28:542-8.

225. Ottesen AH, Louch WE, Carlson CR, Landsverk OJB, Kurola J, Johansen RF, Moe MK, Aronsen JM, Hoiseth AD, Jarstadmarken $\mathrm{H}$, et al. Secretoneurin is a novel prognostic cardiovascular biomarker associated with cardiomyocyte calcium handling. J Am Coll Cardiol. 2015;65:339-51.

226. Pan J, Bear C, Farragher S, Cutz E, Yeger H. Cystic fibrosis transmembrane conductance regulator modulates neurosecretory function in pulmonary neuroendocrine cell-related tumor cell line models. Am J Respir Cell Mol Biol. 2002;27:553-60.

227. Hill DB, Button B. Establishment of respiratory air-liquid interface cultures and their use in studying mucin production, secretion, and function. Methods Mol Biol. 2012;842:245-58.

228. lanowski JP, Choi JY, Wine JJ, Hanrahan JW. Mucus secretion by single tracheal submucosal glands from normal and cystic fibrosis transmembrane conductance regulator knockout mice. J Physiol. 2007;580:301-14.

229. Hoegger MJ, Fischer AJ, McMenimen JD, Ostedgaard LS, Tucker AJ, Awadalla MA, Moninger TO, Michalski AS, Hoffman EA, Zabner J, et al. Impaired mucus detachment disrupts mucociliary transport in a piglet model of cystic fibrosis. Science. 2014;345:818-22.

230. Evans CM, Kim K, Tuvim MJ, Dickey BF. Mucus hypersecretion in asthma: causes and effects. Curr Opin Pulm Med. 2009;15:4-11.

231. Yang N, Garcia MA, Quinton PM. Normal mucus formation requires CAMPdependent $\mathrm{HCO} 3-$ secretion and $\mathrm{Ca} 2+-$ mediated mucin exocytosis. J Physiol. 2013;591:4581-93.

232. Samarasinghe AE, Hoselton SA, Schuh JM. The absence of VPAC2 leads to aberrant antibody production in aspergillus fumigatus sensitized and challenged mice. Peptides. 2011;32:131-7.

233. Nieber K, Baumgarten CR, Rathsack R, Furkert J, Oehme P, Kunkel G, Substance $P$. Beta-endorphin-like immunoreactivity in lavage fluids of subjects with and without allergic asthma. J Allergy Clin Immunol. 1992;90:646-52

234. Ollerenshaw SL, Jarvis D, Sullivan CE, Woolcock AJ. Substance P immunoreactive nerves in airways from asthmatics and nonasthmatics. Eur Respir J. 1991;4:673-82.

235. Dinh QT, Mingomataj E, Quarcoo D, Groneberg DA, Witt C, Klapp BF, Braun A, Fischer A. Allergic airway inflammation induces tachykinin peptides expression in vagal sensory neurons innervating mouse airways. Clin Exp Allergy. 2005;35:820-5.

236. Dinh QT, Groneberg DA, Witt C, Peiser C, Cifuentes LB, Frossard N, Klapp BF, Fischer A. Expression of tyrosine hydroxylase and neuropeptide tyrosine in mouse sympathetic airway-specific neurons under normal situation and allergic airway inflammation. Clin Exp Allergy. 2004;34:1934-41.

237. Cazzola M, Calzetta L, Facciolo F, Rogliani P, Matera MG. Pharmacological investigation on the anti-oxidant and anti-inflammatory activity of $\mathrm{N}$-acetylcysteine in an ex vivo model of COPD exacerbation. Respir Res. 2017;18:26.

238. Cusack D, Cannon D, Skrabanek P, Powell D. Substance P plasma levels in pregnancy and in various clinical disorders. Horm Metab Res. 1979; 11:448-51.

239. Trout L, Corboz MR, Ballard ST. Mechanism of substance P-induced liquid secretion across bronchial epithelium. Am J Physiol Lung Cell Mol Physiol. 2001;281:L639-45

240. Canning BJ. Neurokinin3 receptor regulation of the airways. Vasc Pharmacol. 2006:45:227-34

241. Garcia-Recio S, Gascon P. Biological and pharmacological aspects of the NK1-receptor. Biomed Res Int. 2015;2015:495704

242. Edgerton MD, Chabert C, Chollet A, Arkinstall S. Palmitoylation but not the extreme amino-terminus of $\mathrm{Gq}$ alpha is required for coupling to the NK2 receptor. FEBS Lett. 1994;354:195-9.

243. Nakajima Y, Tsuchida K, Negishi M, Ito S, Nakanishi S. Direct linkage of three tachykinin receptors to stimulation of both phosphatidylinositol hydrolysis and cyclic AMP cascades in transfected Chinese hamster ovary cells. J Biol Chem. 1992;267:2437-42

244. Gallacher DV, Hanley MR, Petersen OH, Roberts ML, Squire-Pollard LG, Yule DI. Substance $P$ and bombesin elevate cytosolic Ca2+ by different molecular mechanisms in a rat pancreatic acinar cell line. J Physiol. 1990; 426:193-207. 
245. Hanley MR, Lee CM, Michell RH, Jones LM. Similar effects of substance $P$ and related peptides on salivation and on phosphatidylinositol turnover in rat salivary glands. Mol Pharmacol. 1980;18:78-83.

246. Komabayashi T, Yakata A, Izawa T, Suda K, Noguchi M, Tsuboi M. Substance P-induced diacylglycerol formation in rat parotid acinar cells. Eur J Pharmacol. 1991;207:329-35.

247. Groneberg DA, Hartmann P, Dinh QT, Fischer A. Expression and distribution of vasoactive intestinal polypeptide receptor VPAC(2) mRNA in human airways. Lab Investig. 2001;81:749-55.

248. Dorsam GP, Benton K, Failing J, Batra S. Vasoactive intestinal peptide signaling axis in human leukemia. World J Biol Chem. 2011;2:146-60.

249. Dickson L, Finlayson K. VPAC and PAC receptors: from ligands to function. Pharmacol Ther. 2009:121:294-316.

250. Mak JC, Barnes PJ. Autoradiographic localization of calcitonin gene-related peptide (CGRP) binding sites in human and Guinea pig lung. Peptides. 1988;9:957-63

251. Drissi H, Lasmoles F, Le Mellay V, Marie PJ, Lieberherr M. Activation of phospholipase C-beta1 via Galphaq/11 during calcium mobilization by calcitonin gene-related peptide. J Biol Chem. 1998;273:20168-74.

252. Kokkoris $S$, Andrews $P$, Webb DJ. Role of calcitonin gene-related peptide in cerebral vasospasm, and as a therapeutic approach to subarachnoid hemorrhage. Front Endocrinol (Lausanne). 2012;3:135.

253. Parker SL, Balasubramaniam A. Neuropeptide Y Y2 receptor in health and disease. Br J Pharmacol. 2008;153:420-31.

254. Misra S, Murthy KS, Zhou H, Grider JR. Coexpression of Y1, Y2, and Y4 receptors in smooth muscle coupled to distinct signaling pathways. J Pharmacol Exp Ther. 2004;311:1154-62.

255. Motulsky HJ, Michel MC. Neuropeptide Y mobilizes Ca2+ and inhibits adenylate cyclase in human erythroleukemia cells. Am J Phys. 1988;255:E880-5.

256. Pellieux C, Sauthier T, Domenighetti A, Marsh DJ, Palmiter RD, Brunner HR Pedrazzini T. Neuropeptide Y (NPY) potentiates phenylephrine-induced mitogen-activated protein kinase activation in primary cardiomyocytes via NPY Y5 receptors. Proc Natl Acad Sci U S A. 2000;97:1595-600.

257. De la Fuente M, Del Rio M, Hernanz A. Stimulation of natural killer and antibody-dependent cellular cytotoxicity activities in mouse leukocytes by bombesin, gastrin-releasing peptide and neuromedin C: involvement of cyclic AMP, inositol 1,4,5-trisphosphate and protein kinase C. J Neuroimmunol. 1993;48:143-50.

Ready to submit your research? Choose BMC and benefit from:

- fast, convenient online submission

- thorough peer review by experienced researchers in your field

- rapid publication on acceptance

- support for research data, including large and complex data types

- gold Open Access which fosters wider collaboration and increased citations

- maximum visibility for your research: over $100 \mathrm{M}$ website views per year

At $\mathrm{BMC}$, research is always in progress.

Learn more biomedcentral.com/submissions 